\title{
Article \\ EU Carbon Diplomacy: Assessing Hydrogen Security and Policy Impact in Australia and Germany
}

\author{
Linda Hancock* and Linda Wollersheim 10 \\ ACES Australian Research Council Centre of Excellence on Electromaterials Science, Alfred Deakin Institute of \\ Citizenship and Globalization, Deakin University, Melbourne, VIC 3125, Australia; \\ linda.wollersheim@deakin.edu.au \\ * Correspondence: linda.hancock@deakin.edu.au
}

check for

updates

Citation: Hancock, L.; Wollersheim, L. EU Carbon Diplomacy: Assessing Hydrogen Security and Policy Impact in Australia and Germany. Energies 2021, 14, 8103. https://doi.org/ $10.3390 /$ en14238103

Academic Editors: Gregory Trencher, Andrew John Chapman and Araz Taeihagh

Received: 31 October 2021

Accepted: 19 November 2021

Published: 3 December 2021

Publisher's Note: MDPI stays neutral with regard to jurisdictional claims in published maps and institutional affiliations.

Copyright: (c) 2021 by the authors. Licensee MDPI, Basel, Switzerland. This article is an open access article distributed under the terms and conditions of the Creative Commons Attribution (CC BY) license (https:// creativecommons.org/licenses/by/ $4.0 /)$.

\begin{abstract}
Hydrogen is fast becoming a new international "super fuel" to accelerate global climate change ambitions. This paper has two inter-weaving themes. Contextually, it focuses on the potential impact of the EU's new Carbon Border Adjustment Mechanism (CBAM) on fossil fuel-generated as opposed to green hydrogen imports. The CBAM, as a transnational carbon adjustment mechanism, has the potential to impact international trade in energy. It seeks both a level playing field between imports and EU internal markets (subject to ambitious EU climate change policies), and to encourage emissions reduction laggards through its "carbon diplomacy". Countries without a price on carbon will be charged for embodied carbon in their supply chains when they export to the EU. Empirically, we focus on two hydrogen export/import case studies: Australia as a non-EU state with ambitions to export hydrogen, and Germany as an EU Member State reliant on energy imports. Energy security is central to energy trade debates but needs to be conceptualized beyond supply and demand economics to include geopolitics, just transitions and the impacts of border carbon taxes and EU carbon diplomacy. Accordingly, we apply and further develop a seven-dimension energy securityjustice framework to the examples of brown, blue and green hydrogen export/import hydrogen operations, with varying carbon-intensity supply chains, in Australia and Germany. Applying the framework, we identify potential impact—risks and opportunities—associated with identified brown, blue and green hydrogen export/import projects in the two countries. This research contributes to the emerging fields of international hydrogen trade, supply chains, and international carbon diplomacy and develops a potentially useful seven-dimension energy security-justice framework for energy researchers and policy analysts.
\end{abstract}

Keywords: carbon diplomacy; EU CBAM; hydrogen; energy security; Australia; Germany; EU; energy policy; regulation

\section{Introduction}

Hydrogen $\left(\mathrm{H}_{2}\right)$ is to play a central role in global and European transitions to lower carbon energy, storage and fuels, but green $\mathrm{H}_{2}$ is still in a development phase, given that over $90 \%$ of $\mathrm{H}_{2}$ is produced from fossil fuels. The European Union (EU) has set ambitious carbon reduction targets, but the transition to renewable energy (RE) remains a challenge, especially for countries reliant on energy imports. This paper has two inter-weaving themes. Contextually, it focuses on the potential impact of the EU's new Carbon Border Adjustment Mechanism (CBAM) in changing the incentives for fossil fuel exporting countries like Australia, to transition to renewable green $\mathrm{H}_{2}$. Countries lacking a price on carbon will be charged for embodied carbon in certain products when they export to the EU. Supply chains reliant on fossil fuels risk being uncompetitive, once the cost of supply chain carbon is factored in. Secondly, we focus on the potential impact of the CBAM by examining two $\mathrm{H}_{2}$ export/import case studies: Australia as a non-EU state with ambitions to export hydrogen and Germany, as an EU Member State reliant on energy imports. Energy security 
is central to energy trade debates, but needs to be conceptualized beyond supply and demand economics often applied at domestic or national levels, to include broader impact risk and opportunity analysis in a world increasingly integrated through global trade [1]. In this regard, we apply and further develop a seven-dimension energy security-justice framework to the example of hydrogen export/import in each of these countries, including analysis of the potential impact of the CBAM for identified $\mathrm{H}_{2}$ operations with varying carbon supply chains.

In flagging these issues, there is a strong ethical dimension to the EU's CBAM and its ambitions on global climate diplomacy, having itself adopted more ambitious targets for EU climate change policies. Containing global warming to 1.5 degrees is an imperative increasingly recognized by the $\mathrm{EU}$ and the international community, as countries experience more frequent and intense extreme climate events [2-8]. These warnings and the links between human-induced climate change and disasters have influenced business, finance, investment risk and insurance underwriting industries to turn away from fossil fuel investment to embrace renewables [2,9-11]. High-level international reports emphasize the threats to global climate security and there is increasing recognition of the justice implications of climate change transitions $[2-4,6-8,10,12]$. In many cases, governments are the policy laggards. These reports also emphasize the urgent need for countries to adopt more ambitious NDCs than committed under the 2015 Paris Climate Agreement (for example [3]). The UNFCCC Executive Secretary Patricia Espinosa has urged collaboration for intergenerational benefit and the role of developed countries to 'leave no voice or solution behind' [12]. This central goal reflects international commitments to balancing economic, social and environmental concerns under the 17 highly interrelated UN Sustainable Development Goals (SDGs) [13]. The International Institute for Sustainable Development points to developed countries' obligations to less developed countries, for loss and damage, finance, adaptation and capacity-building [4]. However, fossil fuel emitting countries like Australia, Saudi Arabia and Russia have been slow to announce more ambitious undertakings [14].

While circular economy, supply chain and product carbon life cycle have been developing over recent years, this research broaches newly emerging challenges of complex carbon supply chain certification systems and cross-border taxing arrangements in international trade. Huge trading entities like the EU domestically applying decarbonization seek a level playing field on international trade. This potentially impacts other countries' moves to impose similar mechanisms, how they operationalize measurement of their nationally determined contributions (NDCs) under the 2015 Paris Agreement, how they factor in both domestic and export supply chain emissions and their impact on less well-developed countries' capacities to prosper and grow in a more carbon-constrained world.

The research seeks to make a novel contribution to hydrogen debates and add to the few existing studies in $\mathrm{H}_{2}$ international supply chains (Chapman's study is an exception [15]). Much of the hydrogen literature is dominated by technical, engineering and economic (demand/supply) analysis, to the exclusion of ethics, governance, policy, politics and international trade/diplomacy. The modified seven-dimension energy security framework seeks to incorporate political and geopolitical, governance, ethical issues, and international carbon border tax schemes into the analysis, in terms of risks and opportunities to energy security (broadly defined).

The CBAM is a new mechanism where the details are yet to be worked out [16]. As a transnational carbon adjustment mechanism, it has the potential to impact international trade in energy and to leverage policy and regulatory changes to carbon pricing internationally and in policy-laggard non-EU fossil fuel energy exporting countries, like Australia or Saudi Arabia, creating a system that can deal with unfair trade by countries lacking a carbon price. There has been little written on new opportunities and risks posed by CBAMs and the prospects for countries exporting hydrogen, for example, to the EU. By focusing on Australian $\mathrm{H}_{2}$ exports into the EU and $\mathrm{H}_{2}$ German imports, our research makes a novel contribution to the field. Other research has focused on the impact of the CBAM on middle-income and developing countries rather than high income countries 
like Australia and Germany [17]; the impact on developing third countries (proposing an indicator that combines exposure and vulnerability, but not as comprehensive of our framework) [18]; specific country impacts (for example, Ukraine) [19]; CBAM impacts on Australian agriculture [20]; the CBAM's environmental effectiveness [21]; and CBAM's impact on carbon leakage [1]. Muller et al.'s review of CBAM-like mechanisms was written prior to the European Commission's CBAM release in July 2021 [22].

We aim to add to these emerging fields by drawing on political science analysis of energy security and CBAM impacts in a case study of two developed countries; one an $\mathrm{H}_{2}$ exporter to the EU and the other an $\mathrm{EU} \mathrm{H}_{2}$ importing Member State. By posing different carbon supply chains for hydrogen produced from fossil fuels or renewables, this research facilitates practical thinking on how a border equalization tax could work across complicated supply chain systems. Moreover, the EU is seeking not only a level playing field for its internal markets, but also to encourage emissions-reduction-laggards through its "carbon diplomacy". With global focus on the imperatives of policy change, carbon diplomacy is a relatively new area of academic discussion to which this research poses timely commentary and a potentially useful seven-dimension energy security-justice framework that can be of use to energy researchers and policy analysts.

In line with the EU, carbon is used here to refer to all greenhouse gases (GHG), rather than only to carbon dioxide $\left(\mathrm{CO}_{2}\right)$ emissions, and includes other gases including methane $\left(\mathrm{CH}_{4}\right)$, nitrous oxide $\left(\mathrm{N}_{2} \mathrm{O}\right)$ and fluorinated gases from industrial/manufacturing processes [23].

\subsection{EU Climate Policy: The CBAM and Carbon Diplomacy}

In July 2021, the European Commission adopted a proposal for the new CBAM, a form of equalization fee between EU producers and foreign exporters lacking a price on carbon. It will initially apply to a select number of goods identified at high risk of carbon leakage: iron and steel, cement, fertilizer, aluminium and electricity generation. The CBAM will be phased in gradually and applied from 2023 in a simplified form [16]. The EU is an interesting climate policy mover with a global focus. As a supranational federal entity that is sui generis (one of its own kind), the EU brings together 27 Member States and represents a huge and powerful trading block. The EU has for a long time identified climate change as an issue not only for its Member States, but as a global concern. In January 2021, the EU confirmed its commitment to a revised NDC, to reduce GHG emissions by at least 55 percent by 2030 compared to 1990 levels and to be implemented through the European Green Deal [24] (p. 2). The EU has worked over the past decades to facilitate its Member States' commitments to enhanced carbon abatement through an emissions trading scheme [ETS]. The Council of the European Union has stipulated that members need 'to align their trade promotion, finance, aid and foreign investment strategies with their domestic climate pledges and Paris Agreement commitments', and has coupled post COVID-19 investment with 'sustainable and climate sensitive economic recovery policies' [24] (p. 3).

The CBAM is therefore more than just an import tax, as it has diplomatic intent. The use of diplomacy here goes beyond standard definitions, like the 'management of relationships between countries' [25]. We draw on an expanded definition of diplomacy, as 'the established method of influencing the decisions and behavior of foreign governments and peoples through dialogue, negotiation, and other measures short of war or violence' [26]. Having identified climate change as an existential threat to humanity, the EU has progressed its global climate change agenda through carbon diplomacy. In this regard, the EU emphasizes the links between climate change and defense and sees climate change as a threat multiplier, impacting international stability and security, and especially impacting the vulnerable. The Council of the European Union argues that ' $(t)$ he European Union needs to urge third countries to intensify their efforts (to transition towards climate neutrality) alongside the European Union' [27] (p. 4).

Thus, the CBAM is not just about trade and EU trade/economic benefit but has global diplomatic aspirations, seeking to influence EU trading partners' emissions policies, or at 
the least, make them pay an equalizing fee. Already, European Commission and Member State discussions on the details of the CBAM point to the need for an agreed carbon supply chain certification system that importers to the EU would need to apply to determine their EU import fee status [28]. The European Commission outlines how the CBAM will work [16]:

Once the definitive system becomes fully operational in 2026, EU importers will have to declare annually the quantity of goods and the amount of embedded emissions in the total goods they imported into the EU in the preceding year, and surrender the corresponding amount of CBAM certificates.

EU importers will buy CBAM carbon certificates applying the carbon price that would have been paid if the products had been produced under the EU's carbon pricing rules. If the importer can prove the equivalent carbon price has already been paid to produce the imported goods, then an adjustment is made and correspondingly deducted for the EU importer [16]. Alongside the CBAM, the EU has announced a phase-out of production subsidies and free pollution permits granted to high-carbon polluting industries and replacement with the border adjustment mechanism 'to tackle carbon leakage in a WTO compatible way' [24] (p. 4). Although the CBAM has been referred to as a tariff or a tax in the media, the Council of the European Union classifies it is 'an environmental policy tool, not a tax, not a tariff' $[29,30]$. The CBAM also addresses the key issue of carbon leakage, as a disincentive to off-shoring of carbon-intensive industries by companies based in the EU. Hence, the CBAM, as adopted in July 2021, has twin objectives [16]:

The CBAM will equalise the price of carbon between domestic products and imports and ensure that the EU's climate objectives are not undermined by production relocating to countries with less ambitious policies. It also aims to encourage industry outside the EU and our international partners to take steps in the same direction.

\subsection{Hydrogen: The New Super Fuel}

Hydrogen has gained urgent global attention as a vital component of decarbonization efforts to contain global warming to 1.5 degrees, giving rise to the emerging field of international hydrogen supply chains. Relecting this priority area, many countries are initiating hydrogen facilitation policies. Internationally, IRENA has identified 'a new wave of attention' for green $\mathrm{H}_{2}$ due to its suitability for hard-to-abate sectors such as heavy transport, but notes that, with 95 percent of global $\mathrm{H}_{2}$ produced from fossil fuels [31], enabling policies are crucial for overcoming the challenges of green $\mathrm{H}_{2}$ production and system integration. Hydrogen has gained priority as a vital contributor to global decarbonization in the EU, in the USA, and by key intergovernmental organizations [32-37]. Hydrogen also features prominently in post COVID-19 energy recovery plans and in several national energy transition plans, including Japan, Germany, Chile, Portugal, Austria, and Australia [38]. Some analysts expect 'that in future, at least $33 \%$ of the world economy could be powered by clean energy for not a cent more than it pays for fossil fuels' [39].

In Australia, the funding agency ARENA has expanded its research to include increased investment in Australian hydrogen supply chains and infrastructure, that will underpin renewable hydrogen initiatives including the Hydrogen Energy Supply Chain (HESC) Project (noting this includes funding for carbon capture and storage (CCS)) [40]. Countries like Australia have the opportunity to claim status as a renewables energy superpower/exporter and lead the energy transition, if they prioritize support of $\mathrm{H}_{2}$ production and export. However, it should also be noted that the geopolitical conversation (discussed later in application of the energy security framework) has frequently been lost in the focus on technical details of $\mathrm{H}_{2}$ production and system integration.

It is critical to distinguish between different hydrogen supply chains. Fossil fuels are currently the dominant energy sources in global $\mathrm{H}_{2}$ production and natural gas and coal account for $95 \%$ of production [35,37,41]. Hydrogen is tagged to different colors depending on the heat/energy source and processing method, including for instance, brown hydrogen 
from brown coal, gray $\mathrm{H}_{2}$ from either coal or gas, blue hydrogen from coal or gas with CCS, and green hydrogen from solar/wind/RE [42]. Hydrogen is especially appropriate for decarbonization of heating, heavy industry (steel, cement, chemical (fertilizer) production), energy storage, heavy transport, and aviation sectors, where batteries and electric charging may fall short of the required energy density [35,37,43-49].

The three main methods of producing hydrogen involve, first, using a fossil fuel feedstock such as coal (coal gasification), or, secondly, natural gas (steam methane reforming), to create hydrogen through a thermochemical reaction. Thirdly, using electrolysis and renewable electricity, water $\left(\mathrm{H}_{2} \mathrm{O}\right)$ is split into hydrogen $\left(\mathrm{H}_{2}\right)$ and oxygen $\left(\mathrm{O}_{2}\right)$. Direct solar water splitting, or photolytic processes, use light energy to split water into hydrogen and oxygen. Thermochemical water splitting uses high temperatures-from concentrated solar power or from the waste heat of nuclear power reactions-and chemical reactions to produce hydrogen and oxygen from water [50].

Hydrogen is a clean energy carrier and emits only water vapor and heat, but no carbon when combusted. However, its carbon footprint depends on the source of energy used in production. Whilst hydrogen is emission-free when used, its green credentials are undermined by the use of fossil fuels as the predominant energy source used in hydrogen production internationally $(95 \%)$. Coal is the most polluting and natural gas has reduced emissions but is still significantly polluting, although experts disagree over the extent of the difference [42,51]. Controversially, in climate policy laggard countries like Australia [14], blue hydrogen (from gas with CCS) is promoted as a "transitional fossil fuel" on the grounds that it emits lower emissions than coal-based hydrogen, a strategy also supported by the IEA [36,52]. Pro coal/gas interests also argue in favor of retrofitting CCS to existing gas (or coal) hydrogen plants, which is criticized as a legitimating argument for the continued use of fossil fuels $[53,54]$.

The importance of government leadership for policy-supported investment is highlighted as a crucial factor for timely technological innovation. Hydrogen production has gained impetus from technological innovations on production methods, hydrogen/ammonia conversions, and the increasingly competitive cost of solar, wind and other RE generation. This points to economically viable low-carbon alternatives driving RE-produced green hydrogen and, more generally, a re-shaped global energy market coupled to decarbonization [9,55-57]. In 2020, gray hydrogen [coal] cost around $€ 1.50$ per $\mathrm{kg}$, blue hydrogen $€ 2-3$ per $\mathrm{kg}$ and green hydrogen €3.50-6 per $\mathrm{kg}$, getting closer to the estimated per tonne carbon price that 'could make blue hydrogen competitive in Europe' as a transition fuel, according to the Gas for Climate consortium [58]. However, Bloomberg predicts that green hydrogen costs could fall $85 \%$ by 2050 , pushing renewable hydrogen under the US $\$ 1 / \mathrm{kg}$ (\$7.4/MMBtu) threshold and undercutting natural gas. Accordingly, 2030 cost forecasts have been revised downwards by $13 \%$ and 2050 forecasts by $17 \%$ [59].

A key driver of this accelerating cost decline is the falling cost of solar PV 'driven by more automatic manufacturing, less silicon and silver consumption, higher photovoltaic efficiency of solar cells and greater yields using bifacial panels' [59]. It is expected that solar electricity will be $40 \%$ cheaper in 2050 than envisaged two years ago [59]. Added to predicted $\mathrm{RE}$ electricity generation cost deceases, green $\mathrm{H}_{2}$ electrolysers constitute a flexible resource where energy can be generated and stored for long periods, for deployment when variable RE production is unavailable, thus constituting a key dimension of high-level RE system integration [37] (p. 11). Low minerals resource countries like Japan regard hydrogen as the low carbon 'fuel of the future,' which 'can generate both electricity and heat through fuel-cells or turbines, leaving only water as a by-product" [60] (p. 210).

The 2020 EU Hydrogen Strategy prioritizes renewable hydrogen to power sectors, especially heavy industry, that are unsuitable for electrification and to provide storage to balance variable RE flows. Renewable hydrogen is seen as playing a key role in sector integration; 'as a feedstock, a fuel or an energy carrier and storage, and has many possible applications across industry, transport, power and buildings sectors' [33]. The EU is adopting a phased approach from 2020 to 2050 with incremental targets [61]. In support 
of a green, climate-neutral, and digital-Europe transition research agenda, the European Commission has committed $€ 10$ billion of funding matched by partners including industry, universities, research organizations, bodies with a public service mission at local, regional, national or international level, and civil society organizations, including foundations and NGOs [62]. Thus, $\mathrm{H}_{2}$ is increasingly a key import for the EU, at least while domestic supply opportunities are developed longer term.

\section{Method: Application of the Seven-Dimension Energy Security-Justice Framework to Australian and German Hydrogen Case Studies in the Context of the EU CBAM}

Both Australia and Germany are federal states with high heavy transport dependency, currently dominated by high fossil fuel use, but suited to hydrogen fuel cell technology innovation and carbon reduction. Both countries have lately prioritized national hydrogen strategies [63,64]. The energy security-justice framework selected for this analysis of Australian and German hydrogen case studies, is based on the framework developed by Sovacool and Mukherjee (2011 [65]) and modified by Hancock and Ralph (2021 [66]). This framework was chosen for the reason that earlier frameworks hark back to an era focused on oil price and national supply security, whereas today's analysis needs to focus on broader environmental, social, geopolitical, ethical, and global sustainability parameters that are incorporated into the chosen framework [67-69].

Sovacool and Mukherjee's index was constructed to compare energy security policy impacts across different countries in a region [70]. It has five dimensions (Availability, Affordability, Technology Development and Efficiency, Environmental and Social Sustainability, and Regulation and Governance). The framework was modified by Hancock and Ralph to add a sixth ethical justice dimension [66], following Cherp and Jewell's three questions [68] (p. 415): 'Security for whom?', 'Security for which values?' and 'Security from what threats?'. They define energy security as 'low vulnerability of vital energy systems', with vulnerabilities denoting a blend of levels of resilience and exposure to risks, that are politically constructed by social actors (influenced by governments, corporations or institutional actors [68]. The notions of just transitions and energy justice link critical social functions and vital energy systems to equitable transitions [71]. Hancock and Ralph's framework is suited to the current analysis because it is designed to ask questions that span fossil fuels and RE, including both national policy/regulation and geopolitical dimensions.

While the framework's sixth dimension could conceivably incorporate ethical/justice implications of the EU CBAM (or other border adjustment mechanisms), this does not adequately recognize what is likely to be a progression to a more global approach to carbon certification and equalization. We therefore added a separate seventh dimension to our energy security-justice framework-Supranational Carbon mechanisms that can also accommodate EU carbon diplomacy. The lack of global non-voluntary or imposed mechanisms and lack of a global agreement on the price of carbon influences this separate seventh dimension. Some of the metrics referred to in Table 1, outlining the applied seven-dimension energy security-justice framework, relate to new RE technology and to international geopolitical questions engaging beyond energy security at the nation state level. Our application of the framework does not quantify the metrics, or weight them, since the main aim is to identify broadly defined energy security risks and opportunities, related where relevant, to the EU CBAM for each dimension for $\mathrm{H}_{2}$ operations of varying carbon emission intensity. Weightings could however be applied in future research.

Interacting with the sixth dimension focus on globally just transitions, the underlying values of the seventh dimension emphasize a level playing field for domestic products/imports on embedded carbon in product supply chains; development of a nonvoluntary import carbon-cost equalization fee; and a value on diplomacy incentivizing lower carbon emission fuel/energy production by trading partners. So far, the proposed EU CBAM incorporates a border levy/tariff on carbon emissions in supply chains to combat (global) climate change, i.e., global insecurity, and a carbon/emissions certification scheme with broader international remit. There is potential for wider application of the mechanism as other institutional, corporate, and government actors support such global efforts. For 
example, depending on how the collected funds are distributed, least-developed countries most impacted by climate change could be beneficiaries of some return from the fees paid by polluters under the CBAM. Internally, funds could assist Member States to transition to renewables. It could well be that, in the future, international justice issues may have greater weighting.

Table 1. Applied seven-dimension energy security-justice framework.

\begin{tabular}{|c|c|c|}
\hline Dimension & Underlying Values & Components \\
\hline 1. Availability & $\begin{array}{l}\text { Self-sufficiency, resource availability, security of supply, } \\
\text { independence, imports, variety, balance, disparity. } \\
\text { Focus on security of supply and/or domestic } \\
\text { production of critical materials for RE technologies. }\end{array}$ & $\begin{array}{ll}- & \text { Security of Supply and Production } \\
- & \text { Dependency/Diversification }\end{array}$ \\
\hline 2. Affordability & $\begin{array}{l}\text { Cost, stability, predictability, equity, justice, reducing } \\
\text { energy poverty }\end{array}$ & $\begin{array}{ll}- & \text { Price Stability } \\
- & \text { Access and Equity } \\
- & \text { Decentralization } \\
- & \text { Affordability }\end{array}$ \\
\hline $\begin{array}{l}\text { 3. Technology } \\
\text { Development and } \\
\text { Efficiency }\end{array}$ & $\begin{array}{l}\text { Investment, employment, technology development and } \\
\text { diffusion, energy efficiency, stockholding, safety and } \\
\text { quality }\end{array}$ & $\begin{array}{ll}- & \text { Innovation and Research } \\
- & \text { Safety and Reliability } \\
- & \text { Resilience } \\
- & \text { Efficiency and Energy Intensity } \\
- & \text { Investment and Employment }\end{array}$ \\
\hline $\begin{array}{l}\text { 4. Environmental and } \\
\text { Social Sustainability }\end{array}$ & $\begin{array}{l}\text { Stewardship, aesthetics, natural habitat conservation, } \\
\text { water quality and availability, human health, climate } \\
\text { change mitigation, climate change adaptation. } \\
\text { Social sustainability, human rights, human (individual) } \\
\text { security, Sustainable Development, positive outcomes } \\
\text { for communities. }\end{array}$ & $\begin{array}{ll}- & \text { Land Use } \\
- & \text { Water } \\
\text { - } & \text { Climate Change } \\
\text { - } & \text { Pollution } \\
\text { - } & \text { Human Security }\end{array}$ \\
\hline $\begin{array}{l}\text { 5. Regulation and } \\
\text { Governance }\end{array}$ & $\begin{array}{l}\text { Transparency, accountability, legitimacy, integrity, } \\
\text { stability, resource curse, geopolitics, free trade, } \\
\text { competition, profitability, interconnectedness, security } \\
\text { of demand, exports. } \\
\text { Foreign policy, international relations, international } \\
\text { treaties. }\end{array}$ & $\begin{array}{ll}- & \text { Governance } \\
- & \text { Trade and Regional } \\
\text { Interconnectivity } \\
-\quad & \text { Competition and markets } \\
- & \text { Knowledge and Access to } \\
& \text { Information } \\
- & \text { Geopolitics/Foreign policy }\end{array}$ \\
\hline $\begin{array}{l}\text { 6. Just and ethical } \\
\text { socio-technical energy } \\
\text { transitions }\end{array}$ & $\begin{array}{l}\text { Values are identified by applying Cherp and } \\
\text { Jewell's [68] three key questions: } \\
\text { - } \quad \text { Security for whom? } \\
\text { - } \quad \text { Security for which values (and interests)? } \\
\text { - } \quad \text { Security from what threats? }\end{array}$ & $\begin{array}{l}\text { - The politics, governance and ethics } \\
\text { of risk and vulnerability. } \\
\text { - } \quad \text { Identifying what is being protected } \\
\text { in the way energy security is being } \\
\text { framed and in whose interests. } \\
\text { - Identifying just and ethical } \\
\text { socio-technical energy transitions. }\end{array}$ \\
\hline $\begin{array}{l}\text { 7. Supranational Carbon } \\
\text { mechanisms }\end{array}$ & $\begin{array}{ll}\text { - } & \text { Level playing field for domestic products/imports } \\
\text { on carbon emissions } \\
\text { - } \quad \text { Non-voluntary import carbon-cost equalization fee } \\
\text { - } \quad \text { Incentivizing lower carbon emission fuel/energy } \\
\text { production by trading partners [carbon diplomacy] }\end{array}$ & 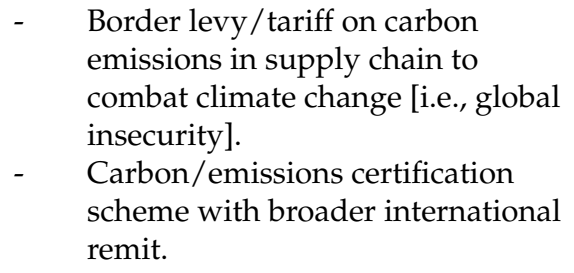 \\
\hline
\end{tabular}

Sources: Sovacool and Mukherjee (2011 [65]) framework as used and modified by Hancock and Ralph (2021 [66]), with the seventh dimension added by this research.

\subsection{Case Studies}

The application of the seven-dimension energy security-justice framework focuses on one non-EU state and one Member State. Australia is the stand-out example internationally of being a high per capita carbon emitter and climate change policy laggard without a 
price on carbon [14]. Germany is reliant on energy imports and bound by tightening of the EU's GHG reduction target and decarbonization policies. At the time of writing, despite going to Glasgow with a commitment to net zero emissions by 2050, Australia's NDC has not changed since the 2015 Paris Agreement of reducing emissions by -26 to -28 percent on 2005 levels by 2030, which is exceptionally unambitious by international standards. This undertaking is clearly inadequate compared to other countries: on the same 1990 levels, -68 percent for the UK, -43 percent for the US and -40 percent for Japan [22] (p. 17). Germany aims to become GHG neutral by 2045, targeting a reduction of GHG emissions by at least -65 percent by 2030 compared to 1990 levels, and -88 percent by 2040. Both countries face decarbonization challenges with fossil fuels comprising 94 percent of Australia's primary energy mix and 80 percent of Germany's in 2018-201919 and much of Australia's export GDP depends on fossil fuels, principally coal and gas [72,73]. Within each country, illustrative $\mathrm{H}_{2}$ production operations with different carbon emission intensities have been chosen from prominent hydrogen projects discussed in industry and government sources. Highlighted projects draw on company annual reports, commentaries, and other related project documents in the identification of risks and opportunities posed by CBAM border taxes for $\mathrm{H}_{2}$ of varying carbon intensity.

\subsection{Australian Selected Hydrogen Projects}

The selected Australian hydrogen projects have been chosen on a continuum of carbon emission intensity from brown through blue to green hydrogen.

\section{i. Brown Hydrogen}

The Australian and Victorian Governments have committed AUD\$100 million to the Australia-Japan partnership Gippsland (brown) Hydrogen Energy Supply Chain-Pilot Project (La Trobe Valley project) [74]. Gippsland's plentiful lignite coal reserves and pilot production commenced in early 2021 with the aim of eventually producing 22,500 $\mathrm{t}$ of hydrogen gas annually with CCS [75]. To meet Japan's requirement for clean hydrogen, the project is predicated upon carbon emissions being sequestered in an offshore reservoir with known subsurface geology suitable for CCS [76]. Japan seeks security of supply for its "hydrogen society" strategy, using hydrogen for transport, electricity, heating and energy storage [77] (p. 77) [78-82]. The project has Japanese Government and energy corporate backing with a consortium of industry partners from Japan and Australia [83].

Under this project, brown coal is gasified at the AGL Loy Yang Complex to produce hydrogen-rich syngas. The syngas is then purified, and the produced hydrogen transported to the Port of Hastings where it will be liquefied and loaded onto a specialized carrier for export to Japan. Kawasaki Heavy Industries Ltd. has undertaken to build purposebuilt carriers, since shipping liquid hydrogen will require a new fleet, and shipping and safety standards were incorporated in the contract signed by Maritime Authorities from both countries in January 2017 [84,85]. Kawasaki Heavy Industries and Iwatani Corp. have partnered with Kobe city to build a liquefied hydrogen import hub by 2020 [86]. CCS is seen by Kawasaki Heavy Industries as central to meeting its requirement for carbon dioxide-(CO2)-free hydrogen [87], and to meeting the Japanese Government's goal of 'an emission-free "hydrogen society" in which hydrogen will be the primary energy medium' [88] (p. 12733). While the pilot is going ahead, CCS is only seen as coming later with the project's expansion for commercialization [35] (p. 50).

\section{ii. Blue Hydrogen}

Santos, Australia's largest LNG exporter plans to produce 'zero emission' export hydrogen from its Moomba and Cooper Basin South Australian natural gas sites, by using CCS to sequester LNG carbon emissions [89]. Santos has aspirations of ramping up LNG exports to 4.5 million tonnes per annum. Santos CEO Kevin Gallagher claims that natural gas 'produces half the GHG emissions of coal when used to generate electricity' [89] (p. 19). It is said to be 'the perfect partner for renewable energy sources and can be made even 
cleaner with carbon capture and storage (CCS), eventually allowing low-cost zero-emission hydrogen, a fuel of the future' [89] (p. 19).

\section{iii. Green Hydrogen}

Two illustrative Queensland large-scale projects are near ports in Gladstone and Townsville in Northern Queensland. Both involve hydrogen produced from electrolysis of water (assuming use of desalinated water in terms of environmental sustainability) [46], using electricity from solar PV as the main power source. The Green Hydrogen Production Plant in Gladstone, Queensland, is owned by Sumitomo Corporation and JGC Holdings Corporation, under a Front End Engineering and Design (FEED) contract, planning to produce 250-300 tonnes of hydrogen annually [90]. The other project under a partnership between Origin Energy and Kawasaki Heavy Industries, is Green Liquid Hydrogen Export Plant in Townsville, planned as a hydrogen port hub [91]. This green hydrogen production facility has an initial scale of $300 \mathrm{MW} / 36,000$ tonnes per annum of hydrogen production for export and domestic supply. After a feasibility study in 2020, the project started Front End Engineering and Design (FEED) studies in 2021 [92].

\subsection{German Selected Hydrogen Projects}

The comprehensive construction of a hydrogen economy has been identified as an elementary building block for Germany's desired total GHG neutrality by 2045. Hydrogen, particularly green hydrogen and its synthesis products are viewed as an integral part for the success of Germany's Energiewende and the full decarbonization of its economy, with total GHG neutrality by $2045[93,94]$. Germany is an interesting case to analyze in the context of the proposed CBAM because it will require a large part of its future hydrogen supply to be imported and likely involve a traded market to supplement home-produced supplies [95].

Prospective German hydrogen import projects have been chosen to represent operations with contrasting carbon emission intensity from blue to green hydrogen.

i. Blue hydrogen

Germany's third-largest listed utility Uniper, headquartered in Düsseldorf (NRW), signed a Memorandum of Understanding (MoU) with Novatek, a leading LNG producer in Russia, in January 2021 on supplying blue and green hydrogen to Uniper's power stations in Russia and Europe [96]. The companies' MoU preceded the signing of a letter of intent between the German and Russian energy ministries in April 2021. Novatek, although not explicitly mentioned in Russia's 2020 Hydrogen Roadmap, has signaled its intentions to take an active part in hydrogen development in Russia [97].

\section{ii. Green hydrogen}

Germany's RWE Supply \& Trading, headquartered in Essen (NRW) and part of RWE AG; the country's second-largest listed utility, signed a MoU with Australian hydrogen project developer Hydrogen Utility Pty Ltd. (H2U) in April 2021 'to explore the possibilities for providing affordable green hydrogen and hydrogen derivatives such as ammonia and synthetic methane to power Germany and Europe's future' [98]. The partnership contributes to a 24-month German-Australian feasibility study, HySupply to determine the viability of a RE-based hydrogen supply chain between the two countries [62,99].

\section{Results}

3.1. Applying the Seven-Dimension Energy Security-Justice Framework to Australian Hydrogen Projects

3.1.1. Availability

The Latrobe Valley project (in the state of Victoria) is promoted as supplying hydrogen for exports (i.e., to Japan) and for 'access to a future clean energy source for domestic use' [83], increasing Australia's diversification and future security of supply of hydrogen. Energy security of supply is a high priority for countries like Japan, which are dependent on 
fossil fuel imports for energy [79-82]. Japan's long-term goals for a low-carbon hydrogen economy are based on multiple international and domestic sources of hydrogen and increasing diversification $[100,101]$. For Australia, planning to supply brown hydrogen produced from Latrobe Valley lignite coal via gasification, there is a real risk of investing into eventually stranded assets, given the high emissions intensity of brown hydrogen (without CCS and critics argue, even with CCS [42]). The Santos Moomba and Cooper Basin LNG hydrogen project in outback South Australia will capitalize on established gas pipelines and infrastructure geared to export. The Queensland projects' green $\mathrm{H}_{2}$ will become increasingly available as production and infrastructure are developed, for hydrogen fuel supply for carbon reduction in previously difficult sectors (e.g., heavy industry, heavy transport, aviation).

\subsubsection{Affordability}

The Latrobe Valley Gippsland project is heavily subsidised and expensive and thus a long way from the commercial aspiration of competitive hydrogen production under US\$1 per kg [39]. Success also depends on improved efficiency in liquification and scaling-up of the liquefied hydrogen tank in the Latrobe Valley project [82], and on keeping shipping costs down. CCS technology forms a key component in the project, but is untested by the pilot which excluded it on cost and technical grounds (discussed later). A further risk is that Japan's goal of reducing hydrogen costs to the level of conventional sources, such as LNG, even if achieved, risks not meeting low carbon requirements.

Proponents favour 'hydrogen from coal with CCS because producing hydrogen through electrolysis is currently more expensive' [83]. However, critics point to the lower emissions and longer-term cost competitiveness of green hydrogen [42] (p. 1685), in view of rapidly decreasing costs of solar and proximity of green hydrogen production to export ports (e.g., Port Headland, Western Australia (WA); Darwin, Northern Territory (NT)), in turn, with greater proximity to Asia than the brown hydrogen production sites in South-East Australian Gippsland. The Santos blue hydrogen project is claimed by CEO Gallagher [89] to be one of the lowest-cost projects in the world at A $\$ 25-30$ per tonne, striving towards the Australian Government's stretch goal to compress, transport and store $\mathrm{CO} 2$ for less than $\mathrm{A} \$ 20$ per tonne, but for gas-generated $\mathrm{H}_{2}$. Queensland-produced solar green hydrogen is forecast to have some of the greatest price efficiencies [102], delivered by the rapidly cheapening cost of solar and the proximity to ports. This will render it more competitive than gray or blue $\mathrm{H}_{2}$ as an export to jurisdictions with a carbon border tax.

For Australia, coal jobs have remained a priority in national policies, but subsidies and policy priorities for fossil fuels risk the opportunity cost of reduced investment in green supply chains. Markets other than Japan, such as the EU, through the import CBAM, may increase costs and bring forward the risks of stranded assets based on fossil fuel generated hydrogen. Hydrogen is seen as large-scale, enabling jobs growth, and long-term electricity and energy storage, thus enhancing international future energy availability and resilience [36]. Purpose-built hydrogen "thermos flask" ships may be more expensive and less efficient than shipping as ammonia in existing shipping, with hydrogenammonia two-way conversions enabled by new membrane technology [103]. The first purpose-built ship launched in December 2019 is ironically powered by diesel [104]. With technological advances in renewables-powered electrolysis and new hydrogen-ammonia conversion, green supply chains may force technological choices that synchronise with climate change ambitions.

However, one of the main hydrogen projects, the Santos Cooper Basin CCS project, is still focused predominantly on LNG with hydrogen a side-line, 'a fuel of the future' [105] (p. 25). Santos describes blue hydrogen as a 'clean combustible fuel' coupled to CCS, seeing its first responsibility as one of displacing coal with gas and 'decarbonising the engine room of global growth', while facilitating more renewable energy by 'firming' (providing electricity when there is no sun or wind) [105] (p. 14). In line with its commitment for gas to replace coal, Santos' 2025 targets are aligned with its natural gas corporate strategy 
and commitment to reducing global emissions. Seemingly at odds with this claim, they say: '(o)ur target is to grow liquefied natural gas exports to at least 4.5 million tonnes per annum by 2025 ' and report 2020 LNG exports of ' 4.3 million tonnes, $45 \%$ higher than 2019' [105] (p. 19). Solar-generated electrolysis $\mathrm{H}_{2}$, however, is becoming increasingly competitive against gas + retrofitted CCS like the Santos project and with recent solar technology, superior on emissions [66].

\subsubsection{Environmental and Social Sustainability}

Due to zero emissions at the point of use, hydrogen is promoted as environmentally sustainable in Australia and by its prospective importer Japan [79-82,106]. The Latrobe Valley Gippsland project, however, represents a now-dated commitment to the use of a highly polluting fossil fuel energy source [lignite coal] justified by CCS for carbon removal and on the flimsy justification of jobs retention, criticised by Environment Victoria as a distraction from focussing 'on real diversification in the valley' [74]. A project-related hydrogen processing facility in the Port of Hastings in Western Port Bay poses environmental risks to ecologically sensitive tidal mangroves and is controversial with local communities [107], and goes against the rising tide of critiques of coal [2,22,108]. With a volatile substance such as hydrogen, there are port-related safety issues in relation to the density of human settlement (there are approximately ten thousand people in the Hastings city area [109]), and the size of holding facilities and ships in close proximity to wetlands. Dredging for shipping has also been controversial in Western Port [74].

At its outback South Australia Cooper Basin project, Santos argues the environmental sustainability of gas replaces higher polluting coal and with CCS constitutes "green energy". Santos CEO Kevin Gallagher claims that 'natural gas, which produces half the greenhouse gas emissions of coal when used to generate electricity . . . . is the perfect partner for renewable energy sources and can be made even cleaner with carbon capture and storage (CCS), eventually allowing low-cost zero-emission hydrogen, a fuel of the future' [105] (p. 8). These misleading claims have been debunked by recent research casting doubt on CCS (discussed later) [110,111].

If CCS is a necessary condition for any climate value of blue $\mathrm{H}_{2}$, clearly this is problematic as the reliability of CCS remains uncertain. Moreover, methane from gas fugutive emissions has serious environmental impacts with a 20-year global warming potential 84-86 times that of CO2 [112,113]. In criticism of CCS, the International Renewable Energy Agency (IRENA) argues that blue hydrogen 'uses finite resources, is exposed to fossil fuel price fluctuations, and does not support the goals of energy security ... (and has) social acceptance issues, as it is associated with additional costs for $\mathrm{CO} 2$ transport and storage and requires monitoring of stored CO2' [37] (p. 9). In contrast, solar-generated hydrogen at the two Queensland projects constitutes green hydrogen and an opportunity for EU tax-neutral exports, and can claim to be 'zero emission' [37], whilst also providing new-economy sustainable jobs.

\subsubsection{Regulation and Governance}

At the national level, governance with transparent, accountable and participatory modes of energy policymaking facilitates energy security [65]. What is viewed as vital is often shaped by its historical significance and the influence of invested institutional interests [68], in this case, the fossil fuel lobby. Consecutive Liberal/National Coalition Governments in Australia have maintained close and intertwined relationships with the fossil fuel industry (see [114]) and continue to prioritise fossil fuels in climate change and energy policies and industry subsidies, posing a risk to GHG reduction. Both the Latrobe Valley Gippsland brown hydrogen project and the Santos Cooper Basin project have received government subsidies (Santos received A $\$ 15$ million national government funding for its CCS development [89]). At the subnational level, Australian State/Territory Governments have in many instances, advanced RE despite unsupportive national policies. 
In terms of trade, foreign policy and geopolitics, hydrogen production for export brings opportunities for Australia and trading partners of benefit to bilateral relations. In 2017, Japan was Australia's second-largest trading partner and second-largest export market, with Australia's major exports to Japan including LNG, coal and iron ore [106]. Australia and Japan work closely in international forums such as the Asia-Pacific Economic Cooperation and East Asia Summit, and share a commitment to democracy, human rights and the rule of law, and common approaches to international security [106]. Irrespective of the energy source of exported hydrogen, geopolitical tensions in the region constitute a risk to shipping and potentially, supply disruptions, due to territorial disputes over sovereign boundaries in the South China Sea [115] (p. 115). Australian industry is pivoting in terms of seeking new markets and strengthening traditional ties with the EU [116].

On trade and foreign policy, where the EU sees a strong link between foreign and security policy and climate change policy, exports of green hydrogen would fare better in terms of policy alignment than fossil fuel produced brown, gray or blue hydrogen. While other countries are pivoting to new opportunities of a renewable energy-driven industrial transition, Australia risks missing first mover advantages by over-looking its potential to develop RE-powered industries that incorporate extraction-to-product value chains given mineral wealth in rare earths (lithium, gold, copper, zinc and nickel) used in electric vehicles, batteries, wind and solar technologies [117]. Australia's lithium and rare earth endowments are seen by the IEA as opportunities for diversifying rare earth production (currently dominated by China) [52]. Such diversification is also seen by Australian commentators as mitigating supply risks for Australia and its allies, with potential geopolitical tensions associated with dependence on China's rare earth and critical materials availability [118].

\subsubsection{Just and Ethical Socio-Technical Transitions}

In terms of "security for whom", recent IPCC reports reinforce the broader and disproportionate impacts of fossil fuels intergenerationally and on disaster-prone countries and vulnerable communities, highlighting the responsibilities of developed countries. Alternatively, RE may support human security internationally by reducing emissions and climate change outcomes, such as possible global food shortages [2,119].

In terms of "security for which values," continued use of fossil fuels (brown coal and gas) such as for the Gippsland and Sandos hydrogen projects, prompts questions regarding the value of global Environmental Security with worsening global warming scenarios under policies enabling high-emission supply chains. Interestingly, Santos is making the same claims as over a decade ago, reiterating 'the role natural gas can play in generating jobs, investment and public revenues, and giving us a cleaner energy mix', claiming that 'with the right policy settings in place, Australian natural gas will deliver environmental, economic and energy benefits for decades, if not centuries, to come' [120]. This shows how both national government climate policy and Australia's biggest LNG producer continue to support the high-carbon energy growth economy and frame LNG hydrogen as 'clean gas'.

Critics argue the company has breached the Corporations Act and Australian Consumer Law by making false claims that gas was a form of "clean energy" and "clean fuels" in its annual report, and have commenced legal action in the Australian Federal Court in April 2021 [111]. The shareholder consumer advocacy group is also critical of Santos' plans to expand its natural gas operations and basing its 2040 GHG net-zero plans on use of unproven technologies like CCS [111]. Both the Gippsland and Santos hydrogen projects, when scaled up, propose 'clean' hydrogen from coal/gas predicated on CCS. Santos sees CCS as a way to 'decarbonise natural gas production and provide the fastest route to a hydrogen-fuelled economy' [121]. However, unless proven on lower carbon, these products will exact an EU carbon border tax.

In terms of "security from what threats", continued carbon emissions on current upward trajectories will mean catastrophic climate events and multiple tipping points [3]. This means that brown and blue hydrogen exports pose extreme risks to global climate and 
human security. This contrasts with the potential of the two Queensland $\mathrm{H}_{2}$ projects and RE technologies, such as concentrated solar power technologies for electricity generation and for concentrated solar fuels including hydrogen and ammonia [122], with the potential to halt escalating global warming in support of fair transitions.

\subsubsection{Supranational Carbon Diplomacy}

This dimension extends beyond national security concerns and prepares for energy security issues that cater for deeper global energy supply chain carbon accounting mechanisms for documenting embodied carbon. The Latrobe Valley Gippsland project strengthens bilateral diplomatic cooperation between Australia and Japan and potentially reinforces the Pacific Quad Alliance between Australia, India, Japan and the US. However, this dimension speaks to global efforts on how to institute polluter-pays in carbon intensive supply chains. Essentially, the opposite of Santos framing LNG as 'natural gas, a fuel for the future, providing clean energy' 'for zero-emissions LNG, hydrogen and other products through carbon capture and storage, nature-based offsets, energy efficiency and use of renewables in its operations' [89] (p. 1).

The design of the EU's CBAM will provide a disincentive to 'resource shuffling,' where carbon-intensive products are exported to countries lacking a border pricing or adjustment mechanism [22] (p. 26). Should the Gippsland pilot project be upgraded to export scale, the success of CCS in containing carbon emissions will be crucial and poses a risk. Changes to Japan's energy policy may also pose a risk, if importing brown hydrogen undermines Japan's revised NDC, up from the goal of -26 percent on 2013 levels to -46 percent in 2030 [123]. Japan has committed two trillion yen (AUD 25.5 bn) over the next decade to support technology investments including hydrogen [124]. Increasingly competitive on price and superior on emissions, green $\mathrm{H}_{2}$ projects will out-compete higher carbon brown and blue $\mathrm{H}_{2}$ and illustrate how the CBAM may represent an opportunity for Australian national policy and $\mathrm{H}_{2}$ industry to back low carbon industries.

\subsection{Applying the Seven-Dimension Energy Security-Justice Framework to German Hydrogen Projects}

\subsubsection{Availability}

Germany's National Hydrogen Strategy predicts a domestic supply gap of 76-96 TWh by 2030 [63]. Beyond 2030, that gap will be even higher, despite a further 5 GW of cumulative electrolysis capacity for the domestic production of green hydrogen planned between 2035 and 2040. While Germany's import preference and the strategy's aim is to build up a European hydrogen network, there is also recognition that EU-produced green hydrogen may not be available at sufficient scale if other EU countries pursue similar hydrogen strategies like Germany [125] (p. 19). Furthermore, limits on available RE sources for hydrogen production are likely on account of competition from direct use of electricity [125] (p. 25) [126] (p. 3).

While the national strategy supports only green hydrogen, other forms of "lowcarbon" hydrogen imports are being considered, including production of blue hydrogen from natural gas with CCS, as considered by the MoU between German Uniper and Russian Novatek (also entailing the production of green hydrogen). Hydrogen is described as a 'clean burning energy source (that) has broad applications to mitigate climate change,' which 'is a promising area for Novatek to develop as part of (its) long-term strategy' by the chairman of the management board of Novatek [127]. The CEO of Uniper highlights the importance of Germany forging international cooperation and partnerships, trusting that '(as) an already trusted supplier of natural gas, Novatek is well prepared to develop export capabilities for Hydrogen' [96]. Novatek is expediting its hydrogen and CCS preparations and expanding its LNG production output 'to up to 70 million tonnes per annum by 2030 and more beyond, in an environmentally responsible manner' in its contribution to 'further decarbonis(e) its already low LNG value chain' [128]. 
To reduce the risk of stranded assets, it is critical that Germany's demand for clean hydrogen and associated German-Russian projects support business models based on $\mathrm{RE}$ and power-to-gas products [129]. Onshore CO2 storage is currently prohibited in Germany [125] (p. 26). Therefore, reforming processes would need to take place in Russia. Novatek is considering 'options to produce hydrogen at downstream consumer sites rather than directly at upstream processing sites (in West Siberia)' [128]. At least for the next decade, Germany will have to rely on imports for hydrogen, pointing to the important consideration of where and at what stage of the value chain hydrogen is produced; the CBAM would have an impact when carbon emissions are factored into import tax.

\subsubsection{Affordability}

Russian (blue) hydrogen is hailed as a competitive and time-saving option and proponents point to existing infrastructure for the transport of gas from Russia to Germany (i.e., Nord Stream 1 and 2 pipelines (e.g., [130]). Pipelines would need to be converted, however, currently only able to transport natural gas with a 5-7 percent hydrogen admixture [131], and, depending on the transportation distances, hydrogen transport via pipeline is expensive costing up to $€ 10 / \mathrm{MWh}$ per $1000 \mathrm{~km}$ [35]. The German RWE and Australian Hydrogen Utility Pty Ltd. (H2U) project-whilst focused on 'providing affordable green hydrogen and derivatives such as ammonia and synthetic methane' [132] —also illustrates the misleading notion of affordability, not accounting for government subsidies needed for project-related infrastructure. RWE plans to import future H2U's green hydrogen via a planned LNG terminal in Brunsbüttel, a town on Germany's North Sea coast [133].

RWE has already secured a substantial share of the import capacity in the highly controversial terminal project that, in addition to the terminal construction itself, seeks to establish a jetty with two berthing facilities for ships up to Q-Max size (the largest LNG carriers worldwide), as well as facilities for distributing LNG by trucks, rail tank cars and smaller ships $[134,135]$. Under the preface of 'becoming a handling facility for hydrogen shipments for the post-fossil fuels future', Germany's first LNG terminal may be built within the next few years (expected to open the market to LNG from the USA, but also from Russia and Australia), receiving double subsidies from federal and state governments totalling more than $€ 100$ million [136,137]. In the longer term, import costs attached to LNG blue hydrogen carbon emissions under the CBAM are likely to render green hydrogen preferable imports.

\subsubsection{Technology Development and Efficiency}

While Germany is investing in green hydrogen projects and the build-up of its domestic RE-based supply chain, bilateral projects implemented by German and Russian companies are unlikely to trigger a profound energy transition in Russia in the next few years [131]. This points to potentially stranded assets in fossil fuel produced hydrogen and carbon-intensive transportation and supply chains as part of German international cooperation, including the Uniper-Novatek project. Rather than committing investment to green hydrogen production, Novatek has ordered a pre-front end engineering and design study into the potential options for a new LNG plant and gas chemistry complex in West Siberia, where it 'will consider producing blue ammonia, hydrogen and other clean-burning fuels, like methanol' [128]. Novatek still presents its major contribution to decarbonising society will be through developing its hydrocarbon resources and bringing more gas to global markets [128].

The RWE-H2U project aims to transport green hydrogen as ammonia from the Eyre Peninsula Gateway Project in South Australia, to Germany's LNG Terminal in Brunsbüttel. As part of the project, $\mathrm{H} 2 \mathrm{U}$ is looking to initially build a $75 \mathrm{MW}$ electrolysis plant on the Eyre Peninsula, which will be big enough to supply 40,000 tonnes of green ammonia per year, with plans to subsequently expand the plant's capacity to $1.5 \mathrm{GW}$ of electrolysis [99]while at some point, there is likely to be 'less development risk (and) a much quicker turnaround for capital for green H2', H2U's Chief Executive Attilio Pigneri, also thinks 
that 'it is worth being flexible and open minded about how the market can develop' [132]. This suggests that, while the market dynamics are clear, at least in the nearer term, the role of blue hydrogen projects with CCS options is not discarded altogether, yet potential risks entail a failure of CCS impacting carbon costs under the CBAM.

\subsubsection{Environmental and Social Sustainability}

A key obstacle to the large-scale import of green hydrogen from Russia is that the Russian Government has made little progress in expanding renewables and there are no long-term government development targets, thus Russia's climate policy is deemed 'critically insufficient' [129]. Rather than drawing on its enormous endowment of wind and solar resources, Russia's hydrogen roadmap primarily aims to develop production capacities in yellow hydrogen (produced from nuclear power) and turquoise hydrogen (produced from natural gas using molten metal pyrolysis) [129], while the Novatek-Uniper $\mathrm{MoU}$ focuses on blue hydrogen from natural gas with CCS, as well as green hydrogen. Germany's focus on green hydrogen in its natioanl strategy supports a decarbonisation agenda that must also be pursued rigorously in international partnerships and bilateral projects implemented between companies. The Green Paradox argument-claiming that if Europe discontinues importing hydrocarbons from Russia, these resources will be sold cheaply to fast-growing economies in Asia, thereby producing no net gains for the global climate [97] — can be called into question, as more global carbon pricing regulations appear in the chain of fossil fuel usage, triggering divestment and the search for more profitable alternatives by affected companies [138].

The large-scale import of green hydrogen and derivatives from Australia will need to ensure that green hydrogen production projects do not come at the expense of local environments, for instance by burdening water supply in water stress-prone areas, which grow worse due to climate change, or by conventional seawater desalination that can come with damaging effects to local marine ecosystems as brine resulting from the purification process is reverted to the sea [139]. The Australian Eyre Peninsula region has also many recorded and unrecorded sites of major cultural significance to Aboriginal people that must be preserved [140]. Free, prior and informed consent must be ensured for the involvement of Indigenous Peoples in decision-making processes about any large projects to warrant highest standards possible and socially sustainable developments [141] (p. 9). In Germany, at the import site, opposition to the planned LNG terminal in Brunsbüttel, stresses that there is neither the need nor, in light of the climate crisis, the time to invest in new fossil gas infrastructure [142]. LNG supporters highlight the dangers of the argument that the infrastructure will be "adaptable", with the government and the joint venture of investors claiming the proposed LNG infrastructure will be fed with bio or synthetic gas further down the line. Carbon supply chain certification measurement under the CBAM has the potential to favour green over LNG hydrogen on price.

\subsubsection{Regulation and Governance}

It is especially important to integrate the hydrogen economy into the general governance of transforming the energy system, resulting in a hierarchical 'energy efficiency first' principle [93]. Priority must be to reduce energy demand, decarbonize the power sector using renewables, and using renewable electricity directly before developing a hydrogen economy [94]. This can help to limit the effects of conversion losses in hydrogen production and limit overall demand for hydrogen.

In terms of trade, foreign policy and geopolitics, the deep security crises between Russia and the West means that any proposal for deeper engagement is controversial. However, if there is political will for cooperation, sustainable energy remains one of the few mutually beneficial and therefore potentially promising areas [97]. Energy trade already requires cooperation to manage the effects of decarbonisation. To minimise any possible new import risks, long-term relationships can be fostered with democratic, politically, and economically stable countries producing hydrogen [94], such as Australia. In view of 
deeper global energy supply chain carbon accounting needs, it is important that Germany applies sustainability criteria to Australia's potential hydrogen export value chain.

\subsubsection{Just and Ethical Socio-Technical Transitions}

In addition to applying sustainability criteria to ensure exporting countries can meet their domestic energy and climate policy goals, measures such as investment support or a guaranteed demand for green hydrogen can help to create attractive market conditions for exporting countries to develop green hydrogen value chains [93]. LNG still entails significant fossil fuel pollutants that bear upon ethical/justice issues impacting vulnerable countries. Furthermore, the creation of quality and stable jobs in hydrogen producing countries and the expansion of local value-added industries are major drivers for the development of a globally networked hydrogen economy in support of just transitions $[94,143]$.

\subsubsection{Supranational Carbon Diplomacy}

The German Federal Ministry of Economic Affairs and Energy announced the operational launch of the H2Global program in June 2021, introducing 'an auction-based mechanism to promote a timely and effective Power-to-X [PtX] market ramp-up on an industrial scale' [144]. Through H2Global, renewable-based green hydrogen or its derivatives can be purchased abroad with long-term contracts and resold in Germany via annual auctions [145]. This aims to facilitate foreign trade partnerships with countries in which green hydrogen can be produced efficiently due to their geographical location, such as Australia. However, the focus of H2Global is also on establishing green hydrogen value chains 'in partner countries where the local energy transition will be supported' [146], having direct implications for countries such as Australia and Russia where government policies continue to emphazise carbon-intensive value chains.

\section{Discussion}

4.1. The CBAM and the Role of Supranational Carbon Diplomacy through Carbon Tax/Adjustment Mechanisms

A CBAM has the potential to support green hydrogen imports, international partnerships and decarbonized domestic Member State industry transitions. Applying the seven-dimension energy security-justice framework to the two country examples in this research assumes that all dimensions are of equal weight. However, as climate change decarbonization becomes more urgent, it might be suggested that dimensions six and seven, related to global impacts, need greater weighting in future uses of the framework.

By aligning ambitious climate change and trade policies, the CBAM replaces EU domestic free emission allowances granted to high emission industries with an internal incentive to reduce emissions and is a potential catalyst for more global carbon certification through cross border trade measures. Other countries are considering similar measures. In the US, the Biden Presidential campaign pledged to 'impose carbon adjustment fees or quotas on carbon-intensive goods from countries that are failing to meet their climate and environmental obligations' [147], and the UK is also considering options for a border levy that could extend carbon pricing internationally [148], with some suggesting a high carbon price rising to $£ 75$ per tonne of carbon by 2030, with leakage measures [149]. Having left the EU, the UK has realized that there could be significant potential impact from the CBAM. Not acting could potentially cost $€ 1$ billion or more, with exporters of steel hit particularly hard by the CBAM [149]. In tandem with the EU, they suggest [149] (p. 1):

a robust policy package to support industrial decarbonisation, including linking of emissions trading systems, equitable CBAM design, the gradual phase-out of free allocation of permits, support for innovation, and carbon contracts for difference.

\subsection{Limitations of the $C B A M$}

The CBAM is not a panacea and is only one among a range of policy tools for decarbonization. There are still many unresolved practicalities regarding implementation of the 
CBAM. In the first instance, it will be applied to five energy intensive industry sectors: iron and steel, cement, fertilizer, aluminium, and electricity generation [16]. Details remain under discussion on how to assess their carbon content, whether and how to factor in the climate policies and development status of exporting countries, and how revenues will be used. To date, the CBAM is limited to Scope 1 and Scope 2 emissions under the Greenhouse Gas Protocol, but Scope 3 emissions (also important) would render it too complicated in the immediate future [149].

Instead of countries carefully weighing self-interest against a realistic carbon price for their energy system reform, global settings and carbon certification may no longer be a choice. Australia 'has one of the most fossil fuel-based and emissions-intensive economies of all economically developed countries', and there is the real risk that Australia will be left behind if countries like the 'EU, UK, China, Japan, Korea, New Zealand, Canada and even parts of the US impose carbon prices' [22] (p. 3). If carbon emissions on end-product exports to the EU require carbon certification across complex supply chains, including Australian exports to the EU, it will be complicated and expensive for businesses to implement. It could mean that displaced or higher embodied fossil fuel emissions will be taxed, and that EU Member State importers find it administratively onerous, making Australian end-products potentially uncompetitive.

The EU's carbon diplomacy's potential to leverage policy and regulatory changes towards net zero emissions in EU Member States is likely to be greatest in CBAM productsimport-dependent EU countries. Bulgaria, Ireland, and Greece (especially specific companies in these countries) are expected to be most exposed to the CBAM as they potentially face higher input cost, with around 60 percent of their total imports of the CBAM products coming from non-EU regions [150]. A key concern for EU Member States with exportoriented economies, such as Germany, is the potential threat of retaliatory countermeasures from trading partners in response to the CBAM [151]. It is thus important to consider how the CBAM might affect risks and opportunities for different EU Member States. In the case of Germany, the comprehensive construction of a hydrogen economy has been identified as an elementary building block for its desired total GHG neutrality by 2045, with the CBAM potentially tilting Germany's hydrogen imports towards supply chains based on renewables rather than those including fossil fuels.

\subsection{The Contested and Uncertain Credentials of CCS}

The Australian Government supports CCS and has put CCS at the center of its 2020 Technology Roadmap [152], spending billions on taxpayer funded CCS projects. Just prior to the November 2021 Glasgow COP26, the government included CCS under Australia's taxpayer-funded carbon offset Emissions Reduction Fund [153]. Santos and project partner Beach Energy were awarded a AUS $\$ 15$ million grant from the Australian Government's Carbon Capture Use and Storage Development Fund [89,154]. While companies like Santos are committed to increasing LNG production and export for what they see as expanding LNG markets and 'clean $\mathrm{H}_{2}$ ', this is predicated on the efficacy of retrofitting CCS to hydrogen and electricity gas plants and alongside claimed CO2 reduction of carbon capture [105] (p. 7).

Doubts remain on the pollution and emissions of coal/gas with CCS, due to the coal mining and gas extraction processes and the energy needed for the CCS process, transport, processing, and CO2 storage [15]; costs of CCS [69,110]; safety, affordability and reliability of CCS entailing 'massive new capital costs and entail enormous long-term liabilities' [155] (pp. 4667-4669); onerous testing processes, risks to human settlement and the environment of CO2 leakage [155]; its untested performance in seismically unstable locations [107] and the failed Australian Gorgon CCS pilot [156]. A Cornell and Stanford University 2021 review comparing $\mathrm{CO} 2$ and fugitive emissions from blue $\mathrm{H}_{2}$ and gray $\mathrm{H}_{2}$ (from fossil fuels without CCS) concluded: 'the greenhouse gas footprint of blue hydrogen is more than $20 \%$ greater than burning natural gas or coal for heat and some $60 \%$ greater than burning diesel oil for heat' [42]. This is attributed to the considerable extra gas needed to power the 
carbon capture process. While some of the assumptions of this research are contested [51], its findings cast doubt on the claims of blue $\mathrm{H}_{2}$ as a transition fuel.

Despite considerable government investment, CCS is still of unproven efficacy and claims of indefinite sequestration remain 'an optimistic and unproven assumption' [42] (p. 1676). Australia's only commercial scale CCS project, the AUD\$70 billion Gorgon natural gas facility in WA gained government approval on the assumption that carbon emissions would be sequestered using CCS. Assisted by an AUD $\$ 60$ million grant from the National Government's Low Emissions Technology Demonstration Fund, CCS commenced in August 2019. It was expected to inject and store between 3.4 million and 4 million tonnes of GHG emissions a year once fully operational. However, following delays and a host of problems, the project has failed to meet its targets and Chevron is in private talks with the WA regulator on the cost of paying for its failed carbon abatement (but at the globally low price of AUD\$20 per tonne) [152,156].

There are also doubts about the rate at which CCS could abate emissions at the scale of projected usage rates of fossil fuels. The IEA estimates that meeting the predicted CCS requirement to reduce carbon emissions by $9.5 \mathrm{Gt} \mathrm{CO} 2$ in 2050 , or 19 percent of the total, would require 100 CCS projects by 2020, storing 255 Mtpa [157] (p. 5755) [158]. Research also documents how global targets set for CCS capability by the IEA, the IPCC, the G8, the Australian Government, the Australian Coal Association, and the Council of the European Union, to meet these needs have not been realized [159]. Even if CCS overcomes some of these hurdles, the timeframe into 2030s or longer would stall progress on urgent decarbonization, when in the short-term, investment in a new renewables-based economy is quicker and climatically preferable [159].

\subsection{Summary of Results}

Table 2 summarizes risk and opportunity analysis across the seven dimensions of energy security-justice applied to Australian brown, blue, and green hydrogen export projects. Some forms of hydrogen production enable the continuation of polluting fossil fuel generation, with concomitant risks, whilst green hydrogen projects ultimately offer new opportunities. The Latrobe Valley Gippsland lignite gas hydrogen project and the Santos South Australian blue hydrogen LNG project will compete with recent renewable green solar-generated hydrogen export projects for example, from Gladstone and Townsville, Queensland (QLD), which have cleaner supply chains [15].

Table 3 summarizes risk and opportunity analysis across the seven dimensions of energy security-justice applied to German blue and green hydrogen partner projects. While Germany's national import preference and the hydrogen strategy's aim is to build up a European green hydrogen network, it also considers other forms of "low-carbon" hydrogen imports. The Uniper-Novatek blue hydrogen LNG project will compete with renewable green solar-generated hydrogen export projects from several countries, likely including Australia. The RWE-H2U Eyre Peninsula Gateway project in South Australia (SA) will have cleaner supply chain credentials and would not run the risk of facing additional border levies/tariffs on carbon emissions. 
Table 2. Risk and opportunity analysis across applied seven-dimension energy security-justice framework: Australian projects.

\begin{tabular}{|c|c|c|c|}
\hline Energy Security Dimension & $\begin{array}{c}\text { Brown } \mathrm{H}_{2} \text { lignite Coal } \\
+\mathrm{CCS} \\
\text { Latrobe Valley Gippsland } \\
\text { Australia-Japan Project, VIC }\end{array}$ & $\begin{array}{c}\text { Blue } \mathrm{H}_{2} \\
(\mathrm{LNG}+\mathrm{CCS}) \\
\text { Santos Cooper } \\
\text { Basin Project, SA }\end{array}$ & $\begin{array}{c}\text { Green } \mathrm{H}_{2} \\
\text { Solar Electrolysis } \\
\text { Sumitomo Corporation-JGC } \\
\text { Holdings Corporation Project, } \\
\text { Gladstone, QLD } \\
\text { Origin Energy-Kawasaki Heavy } \\
\text { Industries Project, } \\
\text { Townsville, QLD }\end{array}$ \\
\hline 1. Availability & Opportunity & Opportunity & Opportunity \\
\hline 2. Affordability & $\begin{array}{c}\text { Risk: coal becoming less } \\
\text { competitive against solar } \\
\text { Risk: carbon emissions, CCS cost } \\
\text { risks }\end{array}$ & $\begin{array}{l}\text { Opportunity: gas cheaper } \\
\text { Risk: carbon emissions, } \\
\text { CCS cost risks }\end{array}$ & $\begin{array}{l}\text { Risk: current cost per kg } \\
\text { Opportunity: Future low cost per kg }\end{array}$ \\
\hline $\begin{array}{l}\text { 3. Technology Development } \\
\text { and Efficiency }\end{array}$ & Risk: high emission and CCS & Risk: high emission and CCS & $\begin{array}{l}\text { Opportunity: new low emission, } \\
\text { efficient, technology }\end{array}$ \\
\hline $\begin{array}{l}\text { 4. Environmental and Social } \\
\text { Sustainability }\end{array}$ & $\begin{array}{l}\text { Opportunities: jobs (short term) } \\
\text { Risks: carbon emissions, } \\
\text { environmental risks }\end{array}$ & $\begin{array}{l}\text { Opportunities: jobs (short term) } \\
\text { Risks: carbon emissions, } \\
\text { environmental risks }\end{array}$ & $\begin{array}{l}\text { Opportunities: new RE economy jobs } \\
\text { Opportunities: emission reductions, } \\
\text { environmental benefits }\end{array}$ \\
\hline $\begin{array}{l}\text { 5. Regulation and } \\
\text { Governance }\end{array}$ & Risk: future price on carbon & Risk: future price on carbon & $\begin{array}{l}\text { Risk: lack of coherent, long-term } \\
\text { national climate and energy policy } \\
\text { and international marginalization }\end{array}$ \\
\hline $\begin{array}{l}\text { - National level energy } \\
\text { governance and politics } \\
\text { - } \quad \text { Trade, foreign policy, } \\
\text { and geopolitics }\end{array}$ & $\begin{array}{l}\text { Risks: China's reduced } \\
\text { commodity demand; EU border } \\
\text { import costs }\end{array}$ & $\begin{array}{l}\text { Risks: China's reduced } \\
\text { commodity demand; EU border } \\
\text { import costs }\end{array}$ & $\begin{array}{l}\text { Opportunity: increased RE H2 trade } \\
\text { with EU, potential strengthened } \\
\text { domestic emissions laws and NDC }\end{array}$ \\
\hline $\begin{array}{l}\text { 6. Just and ethical } \\
\text { socio-technical energy } \\
\text { transitions }\end{array}$ & $\begin{array}{l}\text { Risk: brown } \mathrm{H}_{2} \text { exports pose } \\
\text { extreme risks to global climate } \\
\text { and human security and unjust } \\
\text { transitions }\end{array}$ & $\begin{array}{l}\text { Risk: blue } \mathrm{H}_{2} \text { exports pose } \\
\text { extreme risks to global climate } \\
\text { and human security and unjust } \\
\text { transitions }\end{array}$ & $\begin{array}{l}\text { Opportunity for fair transitions and } \\
\text { advantages under the CBAM }\end{array}$ \\
\hline $\begin{array}{l}\text { 7. Supranational Carbon } \\
\text { mechanism impacts on } \\
\text { exports/imports }\end{array}$ & $\begin{array}{l}\text { Risk: Brown } \mathrm{H}_{2} \text { will attract high } \\
\text { border tax }\end{array}$ & $\begin{array}{l}\text { Risk: blue } \mathrm{H}_{2} \text { will attract high EU } \\
\text { border import tax }\end{array}$ & $\begin{array}{l}\text { Opportunity: Low / no border tax for } \\
\text { green } \mathrm{H}_{2} \text {. CBAM impacts on national } \\
\text { low emissions policies and global } \\
\text { carbon certification schemes for } \\
\text { international trade }\end{array}$ \\
\hline
\end{tabular}

Table 3. Risk and opportunity analysis across applied seven-dimension energy security-justice framework: German projects.

\begin{tabular}{|c|c|c|}
\hline Energy Security Dimension & $\begin{array}{c}\text { Blue } \mathrm{H}_{2} \\
\text { (LNG + CCS) } \\
\text { Uniper-Novatek Project, West Siberia } \\
\text { (Import from Russia) }\end{array}$ & $\begin{array}{c}\text { Green } \mathrm{H}_{2} \\
\text { Solar Electrolysis } \\
\text { RWE Supply \& Trading-H2U Project, } \\
\text { Eyre Peninsula, SA } \\
\text { (Import from Australia) }\end{array}$ \\
\hline 1. Availability & $\begin{array}{l}\text { Risk: onshore } \mathrm{CO}_{2} \text { storage prohibited in } \\
\text { Germany } \\
\text { Risk: production and transportation capacities }\end{array}$ & $\begin{array}{l}\text { Opportunity: reliable, low-cost supply } \\
\text { Risk: transportation capacities }\end{array}$ \\
\hline 2. Affordability & $\begin{array}{l}\text { Opportunity: gas cheaper } \\
\text { Risk: carbon emissions, CCS cost risks }\end{array}$ & $\begin{array}{l}\text { Risk: current cost per kg } \\
\text { Opportunity: future low cost per kg }\end{array}$ \\
\hline 3. Technology Development and Efficiency & Risk: CCS & Opportunity: new technology \\
\hline 4. Environmental and Social Sustainability & $\begin{array}{l}\text { Opportunities: jobs } \\
\text { Risks: carbon emissions, environmental risks } \\
\text { Risk: new transport (port) infrastructure }\end{array}$ & $\begin{array}{c}\text { Opportunities: jobs } \\
\text { Opportunities: emission reductions, } \\
\text { environmental benefits } \\
\text { Risk: new transport (port) infrastructure }\end{array}$ \\
\hline
\end{tabular}


Table 3. Cont.

\begin{tabular}{|c|c|c|}
\hline Energy Security Dimension & $\begin{array}{c}\text { Blue } \mathrm{H}_{2} \\
\text { (LNG + CCS) } \\
\text { Uniper-Novatek Project, West Siberia } \\
\text { (Import from Russia) }\end{array}$ & $\begin{array}{c}\text { Green } \mathrm{H}_{2} \\
\text { Solar Electrolysis } \\
\text { RWE Supply \& Trading-H2U Project, } \\
\text { Eyre Peninsula, SA } \\
\text { (Import from Australia) }\end{array}$ \\
\hline $\begin{array}{l}\text { 5. Regulation and Governance } \\
\text { - } \quad \text { National level energy governance } \\
\text { and politics } \\
\text { - Trade, foreign policy, and } \\
\text { geopolitics }\end{array}$ & $\begin{array}{c}\text { Risks: CBAM administrative burden on } \mathrm{H}_{2} \\
\text { import companies; lack of coherent, long-term } \\
\text { national climate policy in Russia risks EU border } \\
\text { import costs } \\
\text { Risks: deteriorating EU/Russian relations }\end{array}$ & $\begin{array}{l}\text { Opportunities: increased } \mathrm{RE} \mathrm{H}_{2} \text { production } \\
\text { because of import commitments potentially } \\
\text { leveraging strengthened emissions laws and } \\
\text { NDC in exporting countries }\end{array}$ \\
\hline $\begin{array}{l}\text { 6. Just and ethical socio-technical energy } \\
\text { transitions }\end{array}$ & $\begin{array}{l}\text { Risk: blue } \mathrm{H}_{2} \text { exports pose extreme risks to } \\
\text { global climate and human security and unjust } \\
\text { transitions }\end{array}$ & $\begin{array}{l}\text { Opportunity for fair transitions and advantages } \\
\text { under the CBAM }\end{array}$ \\
\hline $\begin{array}{l}\text { 7. Supranational Carbon mechanism } \\
\text { impacts on exports/imports }\end{array}$ & $\begin{array}{l}\text { Risk: blue } \mathrm{H}_{2} \text { will attract high EU border import } \\
\qquad \operatorname{tax}\end{array}$ & $\begin{array}{l}\text { Opportunity: Low / no border tax for green } \mathrm{H}_{2} \text {. } \\
\text { Increased } \mathrm{RE} \mathrm{H}_{2} \text { production because of import } \\
\text { commitments potentially leveraging } \\
\text { strengthened emissions laws and NDC in } \\
\text { exporting countries }\end{array}$ \\
\hline
\end{tabular}

\section{Conclusions}

This research makes a timely contribution to emerging research on green $\mathrm{H}_{2}$ and carbon border adjustment mechanisms as two inter-weaving themes. Green $\mathrm{H}_{2}$ is becoming more cost-competitive with fossil fuel-generated $\mathrm{H}_{2}$, and offers growth in new RE economy jobs, sustainability benefits, opportunities for increased trade and potential for strengthened domestic emissions laws and NDC undertakings.

The EU CBAM is the first supranational border measure triggering exporting non-EU countries to consider their carbon policy and supply chain compatibility. Underpinning the CBAM is recognition of the close links between climate change and global security and how the ecological transition will reshape global economic, trade and security interests. Accordingly, the CBAM reflects EU carbon diplomacy and a commitment to multilateralism and global cooperation [24]. In the emerging field of carbon border adjustment mechanisms, the CBAM is an important marker in the journey to a system of global carbon adjustment mechanisms and international carbon certification. The central research question examined the potential impact of the EU CBAM on fossil fuel-generated as opposed to green hydrogen imports; since the CBAM puts a cost on carbon emissions embodied in import products' supply chains in fairness to the EU's internal market carbon price.

We examined, hypothetically, how the EU CBAM might impact on Australia as a global exporter of hydrogen and synthetic fuels, including brown, blue, and green hydrogen and how it might impact on German hydrogen importers of producers of blue and green $\mathrm{H}_{2}$, already subject to EU carbon taxes and EU climate policy targets. Rather than focusing on supply-demand economic factors related to the CBAM's impact, this research demonstrates the usefulness of a modified multidimensional energy securityjustice framework, building on the work of Sovacool and Mukherjee [65] and Hancock and Ralph [66]. A new seventh dimension emphasizes supranational global commons decarbonization through carbon/trade diplomacy. Empirically, we applied the modified multidimensional energy security framework to selected hydrogen production operations in Australia and Germany, in the context of their national over-arching climate change and energy policies.

Key findings highlight the risks of fossil fuel-generated brown and blue $\mathrm{H}_{2}$ in comparison with green $\mathrm{H}_{2}$ across the seven energy security-justice dimensions in the Australian and German case study projects. Australian national policy lock-in to gas as a "transitional fuel" and continued support for blue $\mathrm{H}_{2}$ based on gas with dubious claims to the efficacy of CCS, risks the Australian hydrogen industry losing first mover advantages of green $\mathrm{H}_{2}$ based on Australia's natural RE endowments. Global moves to divest from fossil fuels risks stranded assets, a delayed jobs transitions, and lost opportunities for 
new vertically integrated $\mathrm{RE}$ industries (such as battery, solar innovation and green $\mathrm{H}_{2}$ and green product export supply chains). Consideration of the impact of the CBAM as a precursor to other similar cross-border carbon taxes means that Australia's continued support for fossil fuel-generated $\mathrm{H}_{2}$ risks longer term international marginalization and negative trade impacts.

For Germany, the EU is driving ambitious climate change undertakings, so it is vital that investors consider sustainability criteria sufficiently: including emissions intensity of hydrogen supply chains and exporters' domestic energy and climate policy goals. As a net importer of hydrogen at least in the medium term, the research illustrates how some long-term importer/exporter German partnerships with Russia and Australia facilitate hydrogen production based on fossil fuel expansion, thereby locking in continued emissions pollution and environmental degradation. Partnerships developing green hydrogen projects ultimately offer new opportunities, yet also need to ensure they do not come at the expense of local environments and communities in exporting countries and do not co-facilitate fossil fuel infrastructure (i.e., LNG terminals) in the near-/medium-term based on the dangerous argument of "adaptable" infrastructure [142].

In terms of limitations, some may argue exports to the EU of declining importance given Australian business tilting more to exports to the Asia/Pacific region. The Australian Industry Group argues that aluminium, iron, steel and fertilizer make up just 0.25 percent of Australia's goods exports to the EU and the proposed CBAM would not have a significant effect on Australia's major EU exports [160]. However, it might also be argued that traditional markets are important, and the EU is an established market with consistent, deep trading ties to Australia and strong diplomatic relations. The future market for hydrogen imports to Europe is estimated to be worth between $€ 100-700$ billion per year [93]. Hydrogen also represents a new and potentially expanding export for Australia to the EU. Potentially more trade will be affected, as more countries adopt CBAM-type policies with wider product coverage and as carbon certification in product supply chains is incorporated into global standards beyond the five industries identified by the EU in relation to the CBAM. Amidst escalating tensions over trade with China, Australian industries are seeking alternative markets; and Australia is currently in free trade bilateral discussions with the UK, which is also on a trajectory to be consistent with EU CBAM provisions [52,149]. Future research could apply the energy security framework to other EU trading relationships, investigate the impact on third countries in EU import supply chains, and integrate consideration of more accurate carbon certification as part of NDC reporting.

Also evident from our research, accelerating the production of green hydrogen (and development of a low / zero carbon economy, industries) needs government as a catalyst and enabler, not a hinderance. Remaining barriers for green hydrogen that are critical to overcome include cost, infrastructure, energy losses during processing, lack of value recognition, and problems demonstrating sustainability [37] (p. 13), complexities of electrolysis-generated green hydrogen being exported into fossil fuel supply infrastructure, and supports for the development of distributed energy. While countries like Germany are investing in $\mathrm{RE}$, fossil fuel $\mathrm{H}_{2}$ partnerships risk carbon lock-in and current Australian government pro-fossil fuel policies put pressure on the cost of capital, risking loss of first mover competitive advantage in the emerging global race for a zero-carbon economy.

Author Contributions: Conceptualization, L.H.; methodology, L.H.; formal analysis, L.H., L.W.; investigation, L.H., L.W.; resources, L.H., L.W.; data curation, L.H., L.W.; writing-original draft preparation, L.H., LW; writing-review and editing, L.H., L.W.; supervision, L.H.; project administration, L.H.; funding acquisition, L.H. All authors have read and agreed to the published version of the manuscript.

Funding: The Australian Research Council (ARC) Centre of Excellence Scheme (Project Number CE 140100012: ARC Centre of Excellence for Electromaterials Science) provided financial support for the conduct of the research but played no role in the writing of the report; and in the decision to submit the article for publication. 
Conflicts of Interest: The authors declare no conflict of interest.

\section{References}

1. Jakob, M. Climate policy and international trade-A critical appraisal of the literature. Energy Policy 2021, 156, 112399. [CrossRef]

2. IPCC Summary for Policymakers. Global Warming of $1.5^{\circ} \mathrm{C}$. An IPCC Special Report on the Impacts of Global Warming of $1.5^{\circ} \mathrm{C}$ above Pre-Industrial Levels and Related Global Greenhouse Gas Emission Pathways, in the Context of Strengthening the Global Response to the Threat of Climate Change; Masson-Delmotte, V., Zhai, P., Pörtner, H.-O., Roberts, D., Skea, J., Shukla, P.R., Pirani, A., Moufouma-Okia, W., Péan, C., Pidcock, R., et al., Eds.; World Meteorological Organization: Geneva, Switzerland, 2018 ; p. 32.

3. IPCC Summary for Policymakers. Climate Change 2021: The Physical Science Basis. Contribution of Working Group I to the Sixth Assessment Report of the Intergovernmental Panel on Climate Change; Masson-Delmotte, V., Zhai, P., Pirani, A., Connors, S.L., Péan, C., Berger, S., Caud, N., Chen, Y., Goldfarb, L., Gomis, M.I., et al., Eds.; Cambridge University Press: Cambridge, UK, 2021.

4. IISD Highlights and Images of Main Proceedings for 17 June 2021. Available online: https:/ / enb.iisd.org/climate/UNFCCC/SB 2021/highlights-and-images/17June2021?utm_medium=email\&utm_campaign=ENBUpdate-18June2021\&utm_content=ENB Update-18June2021+CID_034ad6d31278d1958edb5bec80ace5cb\&utm_source=cm\& (accessed on 30 September 2021).

5. UNDRR Hyogo Framework for Action 2005-2015: Building the Resilience of Nations and Communities to Disasters-Mid Term Review 2010-2011. Available online: https:/ / www.undrr.org/publication/hyogo-framework-action-2005-2015-building-resilie nce-nations-and-communities-disasters (accessed on 30 September 2021).

6. UNDRR Sendai Framework for Disaster Risk Reduction 2015-2030. Available online: https://www.undrr.org/publication/send ai-framework-disaster-risk-reduction-2015-2030 (accessed on 30 September 2021).

7. UNDRR UNDRR Strategic Framework 2022-2025. Available online: https://www.undrr.org/publication/undrr-strategic-frame work-2022-2025 (accessed on 30 September 2021).

8. United Nations Office for Disaster Risk Reduction. Available online: https:/ / www.unisdr.org/files/47804_2015disastertrendsi nfographic.pdf (accessed on 29 September 2021).

9. Statistical Review. JAMA 1973, 225, 299-306. [CrossRef]

10. Bratman, E.; Brunette, K.; Shelly, D.C.; Nicholson, S. Justice is the goal: Divestment as climate change resistance. J. Environ. Stud. Sci. 2016, 6, 677. [CrossRef]

11. The Reason Fossil Fuel Companies Are Finally Reckoning with Climate Change. Available online: https://time.com/5766188/ shell-oil-companies-fossil-fuels-climate-change/ (accessed on 3 July 2021).

12. UN Climate Change News Patricia Espinosa Outlines the Four Keys to Success at COP26. UNFCCC 2021. Available online: https:/ / unfccc.int/news/patricia-espinosa-outlines-the-four-keys-to-success-at-cop26 (accessed on 5 July 2021).

13. Fonseca, L.M.; Domingues, J.P.; Dima, A.M. Mapping the Sustainable Development Goals Relationships. Sustainability 2020, 12, 3359. [CrossRef]

14. Australia Excluded From Global Climate Talks as Policies Lag, Bloomberg. Available online: https://www.bloomberg.com/ne ws/articles/2020-12-10/australia-excluded-from-global-climate-meeting-as-policies-lag (accessed on 5 August 2021).

15. Chapman, A.J.; Fraser, T.; Itaoka, K. Hydrogen import pathway comparison framework incorporating cost and social preference: Case studies from Australia to Japan. Int. J. Energy Res. 2017, 41, 2374-2391. [CrossRef]

16. European Commission Carbon Border Adjustment Mechanism. Available online: https://ec.europa.eu/taxation_customs/gree n-taxation-0/carbon-border-adjustment-mechanism_en (accessed on 30 September 2021).

17. Eicke, L.; Weko, S.; Apergi, M.; Marian, A. Pulling up the carbon ladder? Decarbonization, dependence, and third-country risks from the European carbon border adjustment mechanism. Energy Res. Soc. Sci. 2021, 80, 102240. [CrossRef]

18. Weko, S.; Eicke, L.; Marian, A.; Apergi, M. IASS Policy Brief. IASS Policy Br. 2020, 6, 1-16. [CrossRef]

19. Chepeliev, M. Possible Implications of the European Carbon Border Adjustment Mechanism for Ukraine and Other EU Trading Partners. Energy Res. Lett. 2021, 2, 21527. [CrossRef]

20. Guerin, T.F. Carbon Tariffs are the Next Border Restriction Facing Australian Exporters. Gov. Dir. 2021, 73, 114-121. [CrossRef]

21. Mörsdorf, G. A, Simple Fix for Carbon Leakage? Assessing the Environmental Effectiveness of the EU Carbon Border Adjustment. Ifo Inst. 2021, 350. [CrossRef]

22. Carbon Border Adjustments: What Are They and How Will They Impact Australia? Available online: https://australiainstitute .org.au/report/carbon-border-adjustments/ (accessed on 2 August 2021).

23. European Commission EU Emissions Trading System (EU ETS). Available online: https://ec.europa.eu/clima/policies/ets_en (accessed on 30 September 2021).

24. Council Conclusions on Climate and Energy Diplomacy-Delivering on the External Dimension of the European Green Deal. Available online: https://www.consilium.europa.eu/media/48057/st05263-en21.pdf (accessed on 3 August 2021).

25. Cambridge English Dictionary Diplomacy I Meaning in the Cambridge English Dictionary. Available online: https:/ dictionary .cambridge.org/dictionary/english/diplomacy (accessed on 2 August 2021).

26. Diplomacy. Available online: https://www.britannica.com/topic/diplomacy (accessed on 2 August 2021).

27. Climate Change and Defence Roadmap. Available online: https://data.consilium.europa.eu/doc/document/ST-12741-2020-I NIT/en/pdf (accessed on 5 July 2021). 
28. Berlin Energy Transition Dialogue Opening Panel: The Green Decade-The Road to 2030. Available online: https://www.yo utube.com/watch?v=D1N9Q-IM08g\&list=PLrJT1Nf7EHwHYWlrATWJ40sXikTEMB5Jq\&index=7 (accessed on 25 September 2021).

29. Council of the European Union Council Conclusions on Climate Diplomacy. Available online: https:/ / data.consilium.europa.eu /doc/document/ST-5033-2020-INIT/en/pdf (accessed on 6 July 2021).

30. EU Plan for World's First Carbon Border Tax Provokes Trading Partners. Available online: https://www.ft.com/content/de7d 12e2-0d04-43d4-b38c-cf795854a4a2 (accessed on 17 July 2021).

31. International Renewable Energy Agency. Green Hydrogen Supply: A Guide to Policy Making; IRENA: Abu Dhabi, United Arab Emirates, 2021.

32. Fuel Cells and Hydrogen 2 Joint Undertaking. Hydrogen Roadmap Europe: A Sustainable Pathway for the European Energy Transition, 1st ed.; Publications Office of the European Union: Luxembourg, Belgium, 2019.

33. European Commission Powering a Climate-Neutral Economy: Commission Sets out Plans for the Energy System of the Future and Clean Hydrogen. Available online: https:/ / ec.europa.eu/commission/presscorner/detail/en/ip_20_1259 (accessed on 2 August 2021).

34. Office of Fossil Energy. Enabling A Low-Carbon Economy; US Department of Energy: Washington DC, USA, 2020.

35. The Future of Hydrogen. Available online: https://www.iea.org/reports/the-future-of-hydrogen (accessed on 20 May 2021).

36. Net Zero by 2050. Available online: https:/ /www.iea.org/reports/net-zero-by-2050 (accessed on 20 May 2021).

37. International Renewable Energy Agency. Green Hydrogen: A Guide to Policy Making; IRENA: Abu Dhabi, United Arab Emirates, 2020

38. Sustainable Recovery. Available online: https://www.iea.org/reports/sustainable-recovery (accessed on 20 May 2021).

39. BloombergNEF Forecasts Green Hydrogen should be Cheaper than Natural Gas by 2050 in Some Markets; Falling Costs of Solar PV Key. Available online: https://www.greencarcongress.com/2021/04/20210407-bnef.html (accessed on 6 August 2021).

40. Arena's Investment Plan 2019. Available online: https://arena.gov.au/assets/2019/08/2019-arena-investment-plan.pdf (accessed on 20 April 2020).

41. Stockman, L. Burning the Gas 'Bridge Fuel' Myth: Why Gas Is Not Clean, Cheap, or Necessary; Oil Change International: Washington, DC, USA, 2019.

42. Howarth, R.W.; Jacobson, M.Z. How green is blue hydrogen? Energy Sci. Eng. 2021, 9, 1676-1687. [CrossRef]

43. Decarbonizing the Electricity Sector \& Beyond. Available online: https://www.aspeninstitute.org/publications/2019-winter-s ummary-report/ (accessed on 18 July 2019).

44. Climate Analytics The Highway to Paris: Safeguarding the Climate by Decarbonising Freight Transport. Available online: https: //climateanalytics.org/latest/the-highway-to-paris-safeguarding-the-climate-by-decarbonising-freight-transport/ (accessed on 25 September 2021).

45. Meeting the Renewable Energy Target: Innovative Approaches to Financing Renewables in Australia. Available online: http:/ / www.cleanenergyregulator.gov.au/DocumentAssets / Documents / EY\%20report-Meeting\%20the\%20Renewable\%20E nergy\%20Target\%202016.pdf (accessed on 4 August 2021).

46. Geoscience Australia Hydrogen. Available online: https://www.ga.gov.au/scientific-topics/energy/resources/hydrogen (accessed on 30 September 2021).

47. Germany Adds Brown Coal to Energy Exit under Landmark Deal. Available online: https://www.reuters.com/article/us-clima te-change-germany-coal-idUSKBN1ZF0OS (accessed on 16 January 2020).

48. ITF. ITF Transport Outlook 2019; OECD Publishing: Paris, France, 2019. [CrossRef]

49. Trencher, G.; Edianto, A. Drivers and barriers to the adoption of fuel cell passenger vehicles and buses in Germany. Energies 2021, 14, 833. [CrossRef]

50. Office of Energy Efficiency and Renewable Energy Hydrogen Production Processes. Available online: https://www.energy.gov / eere/fuelcells/hydrogen-production-processes (accessed on 30 September 2021).

51. How Green are Green and Blue Hydrogen? Available online: https:/ / www.ammoniaenergy.org/articles/how-green-are-green -and-blue-hydrogen/ (accessed on 7 October 2021).

52. The Role of Critical Minerals in Clean Energy Transitions. Available online: https://www.iea.org/reports/the-role-of-critical-m inerals-in-clean-energy-transitions (accessed on 20 May 2021).

53. Retrofitting CCS to Coal: Enhancing Australia's Energy Security. Available online: https://co2crc.com.au/retrofitting-carbon-c apture-storage-coal-cheaper-solar/ (accessed on 26 July 2021).

54. Campey, T.; Bruce, S.; Yankos, T.; Hayward, J.; Graham, P.; Reedman, L.; Brinsmead, T.; Deverell, J. Low Emissions Technology Roadmap; Report No. EP167885; CSIRO: Canberra, Australia, 2017.

55. Brown, B.; Spiegel, S.J. Coal, Climate Justice, and the Cultural Politics of Energy Transition. Glob. Environ. Polit. 2019, 19, 149. [CrossRef]

56. New Energy Outlook 2021. Available online: https:// about.bnef.com/new-energy-outlook/ (accessed on 30 September 2021).

57. Maggio, G.; Nicita, A.; Squadrito, G. How the hydrogen production from RES could change energy and fuel markets: A review of recent literature. Int. J. Hydrogen Energy 2019, 44, 11371. [CrossRef]

58. Peters, D.; van der Leun, K.; Terlouw, W.; van Tilburg, J.; Berg, T.; Schimmel, M.; van der Hoorn, I.; Buseman, M.; Staats, M.; And, M.S.; et al. Gas Decarbonisation Pathways 2020-2050; Guidehouse: Utrecht, The Netherlands, 2020. 
59. Hydrogen Economy Outlook: Key Messages. Available online: https://about.bnef.com/blog/hydrogen-economy-offers-promi sing-path-to-decarbonization/ (accessed on 30 March 2020).

60. Trencher, G.; van der Heijden, J. Contradictory but also complementary: National and local imaginaries in Japan and Fukushima around transitions to hydrogen and renewables. Energy Res. Soc. Sci. 2019, 49, 209. [CrossRef]

61. 23 European Nations Launch IPCEI Hydrogen. Available online: https://www.electrive.com/2020/12/18/23-european-nations -launch-ipcei-hydrogen/ (accessed on 18 December 2020).

62. International Hydrogen Policy Developments. Available online: https://research.csiro.au/hyresource/international-hydroge n-policy-developments-october-2021-update/ (accessed on 3 August 2021).

63. Federal Ministry for Economic Affairs and Energy. The National Hydrogen Strategy; Federal Ministry for Economic Affairs and Energy: Berlin, Germany, 2020.

64. Australia's National Hydrogen Strategy. Available online: https://www.industry.gov.au/data-and-publications/australias-nat ional-hydrogen-strategy (accessed on 25 September 2021).

65. Sovacool, B.K.; Mukherjee, I. Conceptualizing and measuring energy security: A synthesized approach. Energy-Oxford 2011, 36, 5343. [CrossRef]

66. Hancock, L.; Ralph, N. A framework for assessing fossil fuel "retrofit" hydrogen exports: Security-justice implications of Australia \& rsquo;s coal-generated hydrogen exports to Japan. Energy 2021, 223, 119938. [CrossRef]

67. Cherp, A.; Jewell, J. The three perspectives on energy security: Intellectual history, disciplinary roots and the potential for integration. Curr. Opin. Environ. Sustain. 2011, 3, 202-212. [CrossRef]

68. Cherp, A.; Jewell, J. The concept of energy security: Beyond the four As. Energy Policy 2014, 75, 415-421. [CrossRef]

69. Emissions Gap Report 2019. Available online: https:/ / www.unep.org/resources/emissions-gap-report-2019 (accessed on 26 November 2019).

70. Sovacool, B.K.; Mukherjee, I.; Drupady, I.M.; D'Agostino, A.L. Evaluating energy security performance from 1990 to 2010 for eighteen countries. Energy-Oxford 2011, 36, 5846. [CrossRef]

71. Geels, F.W. Regime Resistance against Low-Carbon Transitions: Introducing Politics and Power into the Multi-Level Perspective. Theory Cult. Soc. 2014, 31, 21. [CrossRef]

72. Arbeitsgemeinschaft Energiebilanzen e.V. Primärenergieverbrauch. Available online: https://ag-energiebilanzen.de/6-0-Prima erenergieverbrauch.html (accessed on 7 August 2021).

73. Department of Industry, Science, Energy and Resources. Australian Energy Update 2020; Australian Energy Statistics: Canberra, Australia, 2020.

74. World-First Coal to Hydrogen Plant Trial Launched in Victoria. Available online: https://www.abc.net.au/news/2018-04-12/co al-to-hydrogen-trial-for-latrobe-valley/9643570 (accessed on 12 April 2018).

75. Hydrogen Energy Supply Chain the Fuel for the Future in Safe Hands. Available online: https://hydrogenenergysupplychain. $\mathrm{com} /$ category/featured/ (accessed on 12 November 2021).

76. Bruce, S.; Temminghoff, M.; Hayward, J.; Schmidt, E.; Munnings, C.; Palfreyman, D.; Hartley, P. National Hydrogen Roadmap; CSIRO: Canberra, Australia, 2018.

77. Strategic Energy Plan. Available online: https://www.enecho.meti.go.jp/en/category/others/basic_plan/5th/pdf/strategic_en ergy_plan.pdf (accessed on 3 July 2021).

78. Online Special Event of Hydrogen Energy Ministerial Meeting Held. Available online: https://www.meti.go.jp/english/press /2020/1015_001.html (accessed on 2 July 2021).

79. METI has compiled a Strategic Road Map for Hydrogen and Fuel Cells. Available online: https://www.meti.go.jp/english/pre ss /2014/0624_04.html (accessed on 4 July 2021).

80. Basic Hydrogen Strategy. Available online: http://www.meti.go.jp/english/press/2017/pdf/1226_003b.pdf (accessed on 4 July 2021).

81. Japan's Energy 2018. Available online: https://www.enecho.meti.go.jp/en/category/brochures/pdf/japan_energy_2018.pdf (accessed on 5 July 2021).

82. Strategic Roadmap for Hydrogen and Fuel Cells. Available online: https://www.meti.go.jp/press/2018/03/20190312001/ 20190312001-3.pdf (accessed on 15 July 2021).

83. Hydrogen Engineering Australia Hydrogen Energy Supply Chain. Available online: https://hydrogenenergysupplychain.com/ about-hesc/ (accessed on 4 July 2021).

84. Australia and Japan Develop Safety Standards for Shipping Liquid Hydrogen. Available online: https://www.amsa.gov.a $\mathrm{u} /$ news-community/news-and-media-releases/australia-and-japan-develop-safety-standards-shipping-liquid (accessed on 4 July 2021).

85. Kawasaki Hydrogen Road: Paving the Way for a Hydrogen-Based Society. Available online: https://global.kawasaki.com/en/h ydrogen/ (accessed on 3 July 2021).

86. The Role of Japanese Renewables and Victorian Brown Coal. Available online: https://www.energy-transition-hub.org/content /japans-transition-hydrogen-society-role-japanese-renewables-and-victorian-brown-coal (accessed on 4 August 2021).

87. Yoshino, Y.; Harada, E.; Inoue, K.; Yoshimura, K.; Yamashita, S.; Hakamada, K. Feasibility study of "CO2 free hydrogen chain" utilizing Australian brown coal linked with CCS. Energy Procedia 2012, 29, 701-709. [CrossRef] 
88. Heuser, P.-M.; Ryberg, D.S.; Grube, T.; Robinius, M.; Stolten, D. Techno-economic analysis of a potential energy trading link between Patagonia and Japan based on CO2 free hydrogen. Int. J. Hydrogen Energy 2019, 44, 12733-12747. [CrossRef]

89. Santos. Annual Report 2020 a Clear Pathway to Net Zero Emissions by 2040; Santos Limited: Sydney, Australia, 2020.

90. FEED Contract for Hydrogen Production Plant in Australia. Available online: https://www.sumitomocorp.com/en/jp/news/ release/2021/group/14270 (accessed on 16 June 2021).

91. Origin Progressing Green Hydrogen Plan for NQ. Available online: https:/ / www.i-q.net.au/energy/origin-progressing-green -hydrogen-plan-for-nq (accessed on 14 July 2021).

92. Origin Energy Green Hydrogen Project Signs Port MOU. Available online: https://www.originenergy.com.au/about/investor s-media/green_hydrogen_project_signs_port_mou/ (accessed on 18 June 2021).

93. What are the Opportunities and Challenges of Importing Green hydrogen? Available online: https://www.isi.fraunhofer.de/en /presse/2020/presseinfo-26-policy-brief-wasserstoff.html (accessed on 5 July 2021).

94. Wietschel, M.; Bekk, A.; Breitschopf, B.; Boie, I.; Edler, J.; Eichhammer, W.; Klobasa, M.; Marscheider-Weidemann, F.; Plötz, P.; Sensfuß, F.; et al. Opportunities and Challenges When Importing Green Hydrogen and Synthesis Products; Fraunhofer Institute for Systems and Innovation Research ISI: Karlsruhe, Germany, 2020.

95. German Hydrogen Economy to Spark Traded Market for Imports: Consultants. Available online: https://www.reuters.com/arti cle/us-germany-hydrogen-imports-idUSKBN23T1JT (accessed on 22 June 2020).

96. Novatek and Uniper Pave the Way for Joint Long-Term Hydrogen Supply and Technology Projects. Available online: https://ww w.uniper.energy / news / novatek-and-uniper-pave-the-way-for-joint-long-term-hydrogen-supply-and-technology-projects (accessed on 8 June 2021).

97. Zabanova, Y.; Westphal, K. Russia in the Global Hydrogen Race. Stiftung Wissenschaft und Politik 2021, $34,8$.

98. RWE and H2U Join Forces to Develop Global Hydrogen Trading between Australia and Germany. Available online: https://www.rwe.com/en/press/rwe-supply-and-trading/rwe-and-h2u-join-forces-to-develop-global-hydrogen-trading-b etween-australia-and-germany (accessed on 5 July 2021).

99. UNSW to lead Australian-German green hydrogen trade feasibility consortium. Available online: https://www.pv-magaz ine-australia.com/2020/11/20/unsw-to-lead-australian-german-green-hydrogen-trade-feasibility-consortium/ (accessed on 5 June 2021).

100. Nagashima, M. Japan's Hydrogen Strategy and Its Economic and Geopolitical Implications; Ifri: Paris, France, 2018.

101. Kiriyama, E.; Kajikawa, Y. A multilayered analysis of energy security research and the energy supply process. Appl. Energy 2014, 123, 415-423. [CrossRef]

102. CSIRO Industry: Hydrogen Large-Scale, Demonstration and Pilot Projects. Available online: https://research.csiro.au/hyresour ce/projects / facilities / (accessed on 2 July 2021).

103. CSIRO Membrane to Fill Gap in Hydrogen Export Market. Available online: https:/ / www.csiro.au/en/News/News-releases/ 2017/Membrane-for-hydrogen-fuel-cells (accessed on 25 September 2021).

104. Kawasaki Launches the World's First Liquid Hydrogen Transport Ship. Available online: https://newatlas.com/marine/kawa saki-worlds-first-liquid-hydrogen-transport-ship / (accessed on 15 December 2019).

105. Santos. Climate Change Report; Santos Limited: Sydney, Australia, 2021.

106. Australian Government Department of Foreign Affairs and Trade Japan Country Brief. Available online: https://www.dfat.gov .au/geo/japan/japan-country-brief (accessed on 15 June 2021).

107. Preserve Western Port Action Group; Phillip Island Conservation Society Preserve Western Port. Available online: http: / / www.preservewesternport.org.au/news (accessed on 2 July 2021).

108. Coal in Decline: Adani in Question and Australia out of Step. Available online: https://www.theguardian.com/environment/ 2017/aug/25/coal-in-decline-adani-in-question-and-australia-out-of-step (accessed on 30 September 2021).

109. Australian Bureau of Statistics 2016 Census QuickStats: Hastings (Vic.). Available online: https:/ / quickstats.censusdata.abs.gov. au/census_services/getproduct/census/2016/quickstat/SSC21136 (accessed on 25 September 2021).

110. Finkel, A. Getting to Zero: Australia's energy transition. Q. Essay 2021, 81, 1-103.

111. Shareholder Group Sues Santos over "Misleading" Claims that Gas is "Clean Energy". Available online: https://reneweconomy .com.au/shareholder-group-sues-santos-over-misleading-claims-that-gas-is-clean-energy/ (accessed on 26 August 2021).

112. United Nations Economic Commission for Europe Methane Management: The Challenge. Available online: https://unece.org/ challenge (accessed on 1 August 2021).

113. Methane Matters. Available online: https:/ / earthobservatory.nasa.gov/features / MethaneMatters (accessed on 7 July 2021).

114. Greenpeace Investigation Unit Dirty Power. Available online: https:/ /actinstapage.greenpeace.org.au/dirtypower (accessed on 15 June 2021).

115. Wilson, J.D. A securitisation approach to international energy politics. Energy Res. Soc. Sci. 2019, 49, 114-125. [CrossRef]

116. EU carbon tariffs to be fought by Australia's own plan. Sydney Morning Her. Available online: https://www.smh.com.au/politics/ federal/liberalisation-not-protectionist-australia-to-fight-eu-s-carbon-tariffs-with-its-own-plan-20210311-p579v9.html (accessed on 30 September 2021).

117. Australia Can Have Zero Emissions and Still Profit from Minerals, Says Ross Garnaut. Available online: https://www.abc.net. $\mathrm{au} /$ news/2020-01-13/ross-garnaut-on-bushfires-scott-morrison-climate-change/11861846 (accessed on 13 January 2020). 
118. Race on for Australian Rare Earth Supplies as Fears Grow over China's Market "Monopoly". Available online: https://www.ab c.net.au/news/rural/2021-07-19/rare-earths-race/100285830 (accessed on 19 July 2021).

119. Kuzemko, C.; Keating, M.F.; Goldthau, A. The Global Energy Challenge: Environment, Development and Security; Macmillan International Higher Education: London, UK, 2015.

120. Natural Gas: Australia's Next Energy Advantage. Available online: https://www.santos.com/wp-content/uploads/2020/02/ 100610_address_to_the_australian_institute_of_energy.pdf (accessed on 12 June 2021).

121. Santos Santos Welcomes CCS and Hydrogen Focus. Available online: https://www.santos.com/news/santos-welcomes-ccs-a nd-hydrogen-focus/ (accessed on 2 August 2021).

122. Japan-A Future Market for Australian Solar Ammonia. Available online: https://nh3fuelassociation.org/2016/09/08/japan-a -future-market-for-australian-solar-ammonia/ (accessed on 17 June 2021).

123. Ministry of Foreign Affairs of Japan Prime Minister Suga's Attendance at the Leaders Summit on Climate. Available online: https:/ / www.mofa.go.jp/ic/ch/page6e_000236.html (accessed on 3 August 2021).

124. Japan's Latest Extra Budget Adds \$210 Billion in Spending. Available online: https://www.bloomberg.com/news/articles/ 2020-12-15/japan-third-extra-budget-sets-out-21-8-trillion-yen-in-spending (accessed on 15 December 2020).

125. Lambert, M.; Schulte, S. Contrasting European Hydrogen Pathways: An Analysis of Differing Approaches in Key Markets; Oxford Institute for Energy Studies: Oxford, UK, 2021.

126. Schulte, S.; Schlund, D. Background National Hydrogen Strategy; Institute of Energy Economics at the University of Cologne Cologne: Cologne, Germany, 2020.

127. Novatek, Uniper Sign Hydrogen MOU. Available online: https://www.offshore-energy.biz/novatek-uniper-sign-hydrogen-m ou/ (accessed on 29 January 2021).

128. Novatek speeds up hydrogen and CCS preparations. Available online: https://www.upstreamonline.com/energy-transition/ novatek-speeds-up-hydrogen-and-ccs-preparations/2-1-1046544 (accessed on 30 July 2021).

129. Hydrogen: A Future Cornerstone of EU-Russia Energy Relations? Available online: https://germanwatch.org/en/19778 (accessed on 15 June 2021).

130. Westphal, K.; Dröge, S.; Geden, O. The International Dimensions of Germany's Hydrogen Policy; Stiftung Wissenschaft und Politik: Berlin, Germany, 2020. [CrossRef]

131. Kardaś, S.; Kędzierski, M. A hydrogen Alliance? The Potential for German-Russian Cooperation in Hydrogen Energy. OSW Commentary 2021, 383.

132. Green Or Blue? The Colour Of Australia's Hydrogen Money. Available online: https://www.woodmac.com/news/opinion/gre en-or-blue-the-colour-of-australias-hydrogen-money / (accessed on 2 August 2021).

133. RWE Plans to Bring Australian 'Green' Hydrogen to Europe. Available online: https://www.reuters.com/business/energy/rw e-plans-bring-australian-green-hydrogen-europe-2021-04-15/ (accessed on 15 April 2021).

134. RWE Supply \& Trading H2 Brunsbüttel. Available online: https://www.rwe.com/en/our-portfolio/innovation-and-technolog y/hydrogen/h2-brunsbuettel (accessed on 2 June 2021).

135. German LNG Terminal Group at Brunsbuettel Seeks Building Permission. Available online: https://www.reuters.com/business /energy/german-lng-terminal-group-brunsbuettel-seeks-building-permission-2021-06-24/ (accessed on 25 September 2021).

136. Regulation Exemptions for the Planned Liquified Natural Gas Terminal in Brunsbüttel. Available online: https://www.europarl .europa.eu/doceo/document/E-9-2021-001353_EN.html (accessed on 25 September 2021).

137. LNG Terminals für Deutschland: Flüssigerdgas Oder Lass Ich Das? Available online: https://www.duh.de/fileadmin/user_up load/download/Projektinformation/Energiewende/LNG-Terminal_Steckbrief_2021-Brunsbüttel_FINAL_WEB.pdf (accessed on 17 August 2021).

138. Disputing the Green Paradox. Available online: https://www.ucl.ac.uk/bartlett/about-us/bartlett-review/bartlett-revie w-2018/ short-stories / disputing-green-paradox (accessed on 17 June 2021).

139. Germany Says Green Hydrogen Imports should not Harm Environment in Partner Countries. Available online: https://www.cl eanenergywire.org/news/germany-says-green-hydrogen-imports-should-not-harm-environment-partner-countries (accessed on 6 October 2021).

140. Regional Development Australia Eyre Peninsula Our People-Regional Heritage Aboriginal History. Available online: https: / / www.rdaep.org.au/our-region/our-people/ (accessed on 9 June 2021).

141. Beyond Zero Emissions. The 10 Gigawatt Vision; Beyond Zero Emissions: Melbourne, Australia, 2019.

142. German LNG Terminal Plans Fuel Anger among Environmentalists. Available online: https://www.dw.com/en/liquefied-nat ural-gas-controversial-terminals-european-green-deal-climate-change-lng/a-52377555 (accessed on 14 February 2020).

143. Wiseman, J.; Wollersheim, L. Building Prosperous, Just and Resilient Zero-Carbon Regions: Learning from Recent Australian and International Experience; University of Melbourne: Melbourne, Australia, 2021.

144. Minister Altmaier: "Making Further Progress on International Market Ramp-up for Green Hydrogen". Available online: https: / / www.bmwi.de/Redaktion/EN/Pressemitteilungen/2021/06/20210614-new-funding-instrument-h2global-launche d.html (accessed on 1 August 2021).

145. CSIRO Germany. Available online: https://research.csiro.au/hyresource/policy/international/germany/ (accessed on 30 July 2021). 
146. H2Global Advisory GmbH H2Global: Shaping the Global Energy Transition. Available online: https://h2-global.de/wp-conte nt/uploads/2021/09/Fact-Sheet-H2Global-Sep.-2021-EN.pdf (accessed on 8 August 2021).

147. Democratic National Committee Plan for Climate Change and Environmental Justice. Available online: https://joebiden.com/c limate-plan/ (accessed on 1 August 2021).

148. 'New protectionism': Australia to Fight Boris Johnson's Green Tariff Bid. Available online: https://www.smh.com.au/politics/fe deral/new-protectionism-australia-to-fight-boris-johnson-s-green-tariff-bid-20210210-p5714j.html (accessed on 14 March 2021).

149. What does an EU Carbon Border Adjustment Mechanism Mean for the UK? Available online: https://www.lse.ac.uk/grantham institute/wp-content/uploads / 2021/04/What-does-an-EU-Carbon-Border-Adjustment-Mechanism-mean-for-the-UK_FULL -REPORT.pdf (accessed on 15 June 2021).

150. The Carbon Border Adjustment Mechanism Explained. Available online: https://economics.rabobank.com/publications/2021/ july/cbam-carbon-border-adjustment-mechanism-eu-explained/\#footnote2intext (accessed on 3 July 2021).

151. Emission Reduction Panacea or Recipe for Trade War? The EU's Carbon Border Tax Debate. Available online: https://www.cl eanenergywire.org/factsheets/emission-reduction-panacea-or-recipe-trade-war-eus-carbon-border-tax-debate (accessed on 23 July 2021).

152. Technology Investment Roadmap: First Low Emissions Technology Statement. Available online: https://www.industry.g ov.au/data-and-publications / technology-investment-roadmap-first-low-emissions-technology-statement-2020 (accessed on 3 August 2021).

153. How the Gas Lobby Captured Morrison's Glasgow Response. Available online: https://www.thesaturdaypaper.com.au/ news / politics/2021/10/30/how-the-gas-lobby-captured-morrisons-glasgow-response/163551240012779\#hrd (accessed on 31 October 2021).

154. As Carbon Capture, Storage Commitments Near $\$ 4 b$, What are the Options for Heavy Industry? Available online: http s: / / www.abc.net.au/news/2021-08-21/taxpayer-bill-for-carbon-capture-and-storage-hits-4-billion/100375854 (accessed on 21 August 2021).

155. Sovacool, B.K.; Cooper, C.; Parenteau, P. From a hard place to a rock: Questioning the energy security of a coal-based economy. Energy Policy 2011, 39, 4664-4670. [CrossRef]

156. Chevron Concedes CCS Failures at Gorgon, Seeks Deal with WA Regulators. Available online: https://reneweconomy.com.au/ chevron-concedes-ccs-failures-at-gorgon-seeks-deal-with-wa-regulators/ (accessed on 19 July 2021).

157. Lipponen, J.; Burnard, K.; Beck, B.; Gale, J.; Pegler, B. The IEA CCS technology roadmap: One year on. Energy Procedia 2011, 4, 5752-5761. [CrossRef]

158. Lipponen, J.; McCulloch, S.; Keeling, S.; Stanley, T.; Berghout, N.; Berly, T. The politics of large-scale CCS deployment. Energy Procedia 2017, 114, 7581-7595. [CrossRef]

159. Sunk Costs: Carbon Capture and Storage will Miss Every Target Set for it. Available online: https://australiainstitute.org.au/re port/sunk-costs-carbon-capture-and-storage-will-miss-every-target-set-for-it/ (accessed on 6 June 2021).

160. Swings and Roundabouts the Unexpected Effects of Carbon Border Adjustments on Australia. Available online: https://www.ai group.com.au/globalassets/news/reports/2021/carbon_border_adjustments_policy_paper.pdf. (accessed on 3 September 2021). 